\title{
المولد بين التاريخ والأدب
}

الأديب الأستاذ فايز علي)

مقدهمة :

المولد احتفال شعبي جامع، لذا تقتضي دراسته بتحاوز الفواصل الموضوعة بين الديانات الكثيرة التي عرفتها مصر عبر تاريخها الحافل. وإذا بنا ونحن ندرس احتفال المولد نعيد تجميع أجزاء التاريخ المقسم لغرض الدراسة إلى عصور متتالية. إن المولد معرض حي للشخصية المصرية وتقاليدها العتيقة التي تأبى أن تندثر سواء كانت روحية دينية، أو فنية تتعلق بالغناء والرقص والموسيقى، أو مادية من طعام وشراب وأزياء، وأنشطة اجتماعية أخرى، وهكذا دواليك .

لعله لا يوجد احتفال أصدق تعبيرا عن روح الشعب المصري خير من " المولد "، ذلك الاحتفال الشعبي الذي تسهم فيه الجماهير مثثلة في طوائف الحرفيين والتجار، ومثلي أجهزة الإدارة، والطرق الصوفية .. الخ، وكان الوالي حينا أو الخليفة حيناً آخر يتقدم تلك الحشود. واحتفال المولد وإن ارتبط بالحضارة الإسلامية - يضرب بجذوره في عمق التاريخ المصري وذلك أنه احتفال شبي تحيا فيه عادات وتقاليد عتيقة ذات روافد مصرية أصلية. والمولد يهيل إلى احتفال آخر ذي طابع شعبي، وهو المأتم، وكلاهما يقتضينا التعريف بالصوفية والتصوف بطريقة إجرائية تناسب غرض البحث، وكلاهما يطرح دور العظماء في مسيرة التاريخ، وقدرقم الكاريزمية في إلهام الجماهير من المريدين والمحبين، الذين بهم يقتدون، وعلى طريقهم يسيرون (1). ربما اشتقت لفظة التصوف من صفاء الروح والقلب، أو الاتشاح بمسوح الصوف التي كان

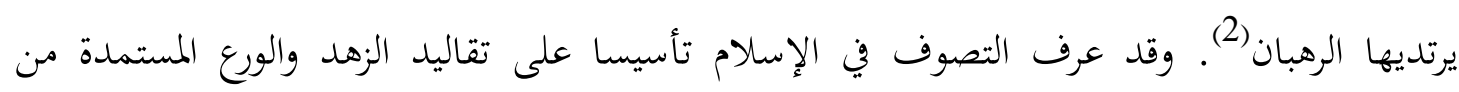
الكتاب والسنة، وإن كانت ثثمة تأثيرات خارجية كتلك الهندية والصينية واليونانية، وإن كان علينا ألا نغفل المؤثرات المصرية القديمة(3)، فهي الأقرب روحيا وإن تكن بعيدة زمنيا نوعا ما. ويمكن تمييز تيارات(4) مختلفة بين التصوف المعرفي والأخلاقي، والسني والشيعي والفلسفي .. وقد ظهر الطرق الصوفية منذ القرن الثاني وانتشرت في القرنين الثالث والرابع الهجريين، فعرف الطريق الذي ينقسم إلى 
مقامات ( كالتوبة والصبر والرضا واليقين .. ) وأحوال (القبض والبسط والفناء والبقاء). حتى صار للمتصوفة مصطلحاقهم ورموزهم.

والفناء من أخص أحوال الصوفية، ويعني فناء الذات البشرية في الذات الإلهية ( عند الجنيد والسقطي والخراز .. )، ويترتب عليه الاتحاد بالله كما قال البسطامي - وهو في صوفية الشطح : سبحاني ما أعظم شأني ! (5) إذ تكلم بلسان الذات الإلهية الحالة فيه. كما يعبر الحلاج (أعدم الداد 301هـ) في شعره عن الحلول : حلول اللاهوت في الناسوت، قال : " أنا من أهوى ومن أهوى أنا -

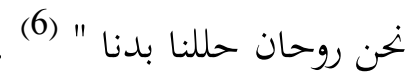
فإذا ما انتفت الثنائية بين الذاتيين كنا بصدد وحدة الوجود، وذلك مذهب ابن عربي

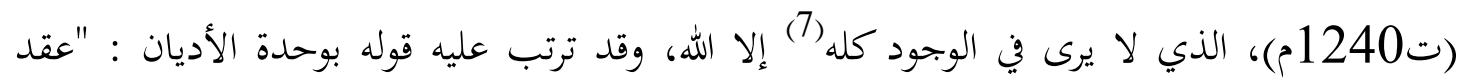

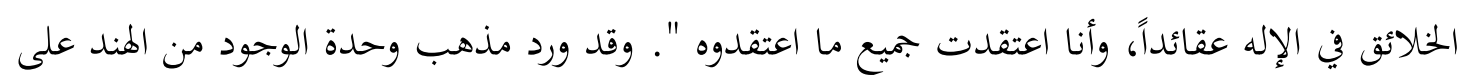
نحو ما يرى البيروني، ولم يصعب على المتصوفة رده إلى القرآن وفق فهمهم : " كل من عليها فان "، " كل شيء هالك إلا وجهه " .. إلخ (8) . كان من أصول التصوف العكوف على العبادة، وبحاهدة النفس، وتنقية الروح كشفا للحقيقة العلوية، سلوكا للمواجد والذوق ... ولكن طرأت تغيرات كبيرة على تلك المفاهيم إيان تفكك الدولة العباسية وما تلا ذلك من توسع دول إسلامية كالدولة العثمانية، وصدام ضد أوروبا، وظهور الصراعات (9) المذهبية .. (إلخ

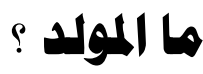
تقدم أن المولد احتفال شعبي جامع، في مناسبة مولد البشير محمد عليه السلام في الثاني عشر من ربيع الأول، وليس هناك ما يشير إلى أن هذا الاحتفال - كميئه المهيبة هذه - كان معروفا على عهد الرسول وصحابته عليهم السلام . ونعتقد أن ذكرى ميلاد محمد كانت موضع اهتمام ما. وإذا كان الفاطميون - كان يقال - هم أول من احتفل بمولد النبي، وهم شيعة كما نعلم، فإن مظفر الدين كوكبوري صاحب أربيل ( ت 1232م ) كان أول حاكم سني يحتفل به (10.) وإن كانت تلك الأوليات لا ينبغي التعويل عليها. 
ولنا رأي سنفصله في تضاعيف هذه الدراسة. وفي البدء نشير إلى أن المولد سرعان ما اتسعت دلالته، فصار يحتفل بموالد أولياء الله الصالحين، وآل البيت، وأصحاب الطرق الصوفية .. وهكذا دواليك . وقد يتعلق احتفال المولد بمناسبة أخرى غير الميلاد، كما هي الحال في مولد العارف بالله أبي الحجاج الأقصري في الرابع عشر من شعبان، وهو ذكر انتصاره على الراهبة المسيحية تريزا ابنة القيصر التي أسلمت على يديه (11) أما السيد أحمد البدوي فله ثلاثة موالد : المولد الكبير والمولد الصغير، والمولد الرجبي (12) ... وهكذا دواليك .. وتلك كلها مواسم زاهر للتجارة والرحلة الدينية والترفيهية .. ويوضح مؤرخنا العلامة على السيد علي أن المولد من حيث الاشتقاق اللغوي يعني مكان الميلاد وزمانه أيضا، فيشير إلى عائلة بن فهد من أهل الحجاز إبان العصر المملوكي والعصر العثماني، وكان يحتفلون بمولد محمد في مكة حيث كان مولده عليه الصلاة والسلام، فتقام الأذكار، وتنحر الذبائح، وتوزع الصدقات (13) .. بيد أننا نتطلع إلى مصر ما قبل الإسلام فنجد احتفال المولد متأصلا عند أسلافنا سواء في المسيحية أو في عصور الفراعنة، الأمر الذي يفسر لنا استمرار تقاليد وطقوس كثيرة لا يمكن فهمها وتأويلها إلا في ضوء المعتقدات القديمة السابقة للإسلام. فقد عرف أسلافنا مولد فرعون وكان مولدا

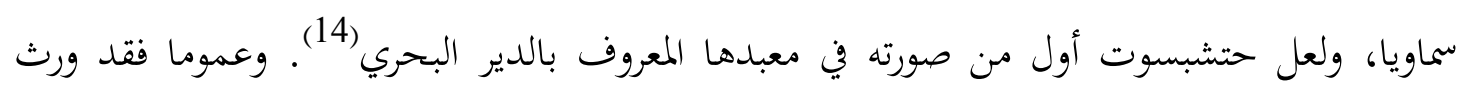
المصري نزعة التجسيد أو الحلول من معتقداته القديمة، التي أبت إلا أن تمتزج بالإسلام في مثل احتفال المولد (15).

\section{تبلي الروح المصري في احتفال المولد :}

تقدم أن العادات والتقاليد من خصائص روح الشعب التي لا تختفي عبر العصور، وإن اعتنق الناس ديانات جديدة غير التي كانوا أسلافهم يدينون ها، وسيمدنا " المولد " بدلائل كثيرة على صحة هذه الفرضية، ونشير هنا بإيجاز إلى بعض تلك الملامح التي نعتقد أهما ظلت ميراثا مشتركا للمصريين على اختلاف بيئاقم وتعدد مشاربهم . 
أول ما يسترعى انتباهنا هو مشهد الخروج إذ تخرج الجماهير عن بكرة أبيها في أزهى حلة وأبهى هيئة لتعبر عن حبوها متشدة في الساحات، التي تعج بمظاهر الاحتفال، فتقام الخيام ليستراح فيها، وتقدم الأطعمة والأشربة. كما ترفرف الأعلام، وتنهمك الجموع في التعبير عن بهجتها في صورة جماعية منقطعة النظير، فتبدو كأها في يوم الحشر. وخير مثال يضرب هو احتفال أوبت (عيد آمون رع) رب الإمبراطورية في الدولة الحديثة(16)

وتتفظ جدران معبد الأقصر بتصوراته، فنرى الكهنة يجرون مركب آمون على ضفاف النيل، ونرى عازف النفير وقارعي الطبول والراقصين والبهلوانات والجمع الغفير يرافق موكب آمون الذي يتقدمه فرعون .. وكانت الخيام تضرب، فضلا عن المقاصير المبنية لاستقبال ذلك الموكب لتقدم شتى وسائل الراحة والتكريء. كان ذلك الاحتفال يستغرق عشرين ونيقا من الأيام ! في عاصمة مصر العالمية : طبية ذات المائة باب التي وصف بماءها وعزها هو ميروس في الإلياذة .. والذي يحضر احتفال مولد أبي الحجاج الأقصري في رحاب مسجده(17) المتكئ على صرح معبد آمون بالأقصر يشده بمظاهر الاتفاق والتشابه التي تصل إلى حد التطابق بين ذلك الاحتفال الشعبي ذي الطابع الإسلامي وعيد آمون الموغل في القدم : الزورق (المقدس) والخيام، والجماهير المبتهجة بين راقصين وموسيقيين وبهلوانات ومملة الأعلام

كذلك تتشابه أنواع المخبوزات والفطائر، وغيرها من القرابين التي كان يتصدق بها لإكرام الضيفان والزوار والمريدين وعابر السبيل .. وإذا بنا نتوارث تعبير القربان المصري القديم : " ألف من الحبز

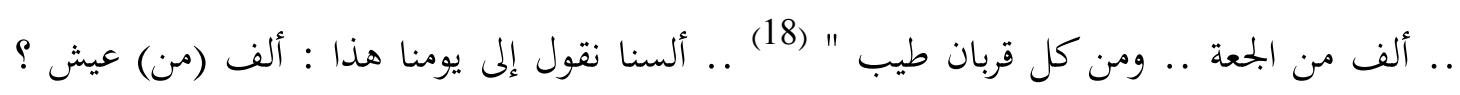
أليس تجهيز الكعك (كيك بالمصرية) والشريك والمنين والبتاو .. من أهم مظاهر الاحتفال بالأعياد حتى يومنا هذا ؟ أليس العيد فعلا مشتقا من المادة والاعتياد " وفرحة قلب ربما اعتاد عيده وفي الاحتفالات الشعبية تنصهر ربما في الوعي أو اللاوعي أو في الذاكرة الجمعية - شتى المناسبات، فإذا أطلقت كلمة موالد فإنها لا تعني مناسبات الميلاد وحدها، بل شتى المناسبات السعيدة : قديمها وحديثها، وفي مقدمتها احتفالات التتويج (تتويج فرعون أو الملك ...) والزواج المقدس (كما في عيد أوبت)، وأعياد النصر، وكل ما اتصل بها أو تفرع عنها من احتفالات فرعية أو طقوس إجرائية(19). 
وبدلا من فرعون الذي كان يشرف على الجماهير المتشدة مكللا بتاج الوجهين يمكن أن نرى الخليفة الفاطمي أو الملك الأيوبي أو السلطان المملوكي أو الخليفة العثماني أو من ينوب عنه من ولاة وأمراء وقضاة وأولى الأمر منه والنهي .. هنالك تلتقي الشعوب بقادتا، والجماهير بساستها، فنعم المناسبة تلك لتأكيد المودة بينهم، وعقد رباط الحمبة. ونعتقد أن الحكام المسلمين كانوا من الذكاء بحيث أدركوا ما لتلك المناسبات من أهمية سياسية فلم يفرطوا في استغلالها .

الطhو|ف-

كذا كان الطواف من الطقوس الهامة، ونعني طواف فرعون بالجدار الأبيض ( منف العاصمة القديمة ) برهانا على أنه يبسط سلطانه على البلاد (20). عرف ذلك الطقس منذ فجر التوحيد السياسي لمصر، وظللنا نحن المصريين نطوف حاملين زوارق الأولياء على الأعناق، وهي نسخة من زوارق الأرباب القدامى، أو حاملين التوابيت والنفوس الرمزية التي تحاكي نعش النعوش أوزير رب الموتى وقاضي المحكمة الآخروية. ولا زال بعض آل البيت أو الأولياء - ومنهم الإمام الشافعي - يلعبون دور ذلك القاضي العدل في معتقداتنا الشعبية .

الطواف المقصود إذن لا علاقة له بالطواف بالكعبة، فيما نرى، وإنما ارتباطه واضح في المخيلة الشعبية على نخو ما أوضحنا، ولعل الطواف بأضرحة الأولياء - يف المعتقد الشعبي - يقر بما بين القدوة والذين به يقتدون، ويزودهم بقبس من إلمامه لعلهم به يهتدون فالولي قطب ( ثابت ) والمريدون يتوافدون

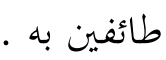

ومن أوزير ؟ إنه القمر (21). نعم، كان القمر يرمز إلى أوزير فالقمر المتناقص حتى الزوال يشير

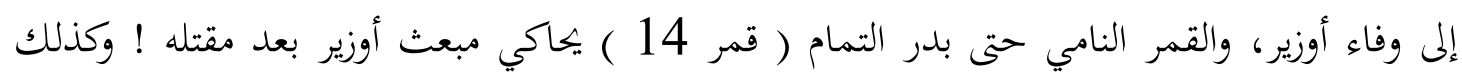
الأئمة والأولياء الصالحون يشبهون بالقمر وبدر التمام، وهم كذلك - مثل أوزير متصفون بالبهاء والحسن، ولا غرو فأوزير يهوز لقب : دائم الحسن ( ونن - نفر ) عندما يبعث من جديد وقد انتصر على الشر (22) . فلنصخ إلى ما قاله المرتضى الزبيدي ( ت 1791 ) في شيخ السادات : هو روح الإله في كل مجلي ... هو تاج الجمال والعلياء 
كنا مولاه أبا الأنوار إذ ... من نوره تتول لدا أنوار

$$
\text { وقد قيل في إمام آخر : }
$$

ولا عجب أن يطلع البدر في الدجى ... بأية وقت شاءه مالك الأمر

(23)

فأصبح مخطوب الجمال ورونق ال ... كما وحامي الحق بالبيض والسمر

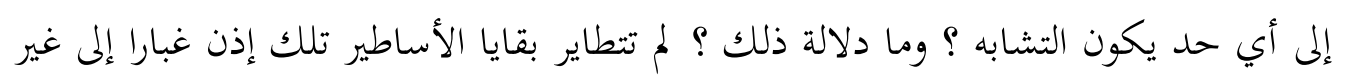
رجعة، تمثلتها الشعراء وأعدوا توظيفها. وليس أفسح من الشعر بحالا تصول فيه أخلية العامة وبتول .

\section{طقس الرحلة النيلية :}

عادة ما ترتبط احتفالاتنا نحن المصريين بالنيل، إذ يبحر الناس مصطحبين أبناءهم، وسط قرع الطبول وإيقاعات البهجة لـازال هذا دأبنا في موالدنا، وهو ما أخبر به هيرودوت حين زار مصر قديما فقال : " ولقد سبق المصريون الشعوب إلى إقامة الأعياد العامة والمواكب العظيمة، وعنهم تعلمها

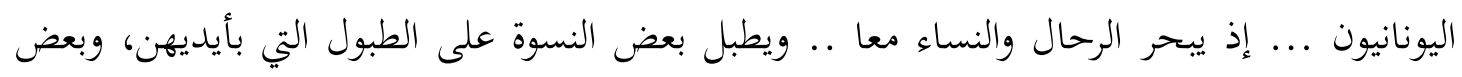
الرجال يزمرون .. أما باقي النساء والرجال فيغنون ويصفقون .. " (24) . قال هيرودوت هذا في معرض حديثه عن الإلة إيزيس في مدينة بوزيريس ( أبو صيربانا، وهو

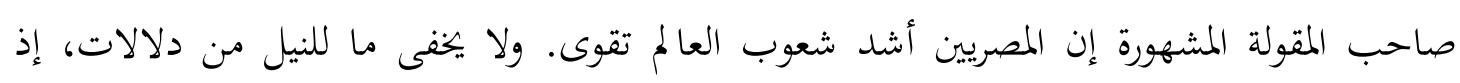
يذكرنا فيضانه السنوي ببعث أوزير من مرقده، وتحدد الحياة في شتى صورها. وثمة روايات لا حصر لها عما كان للنيل من أهمية في حياة مصر كلها، وقد ظل دور النيل قائما باستمرار (25) . 


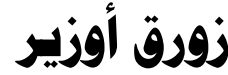

كان لأوزير مقام في أبيدوس قرب عرابة سوهاج المدفونة. وهي تشبه مكة عند المسلمين، إذ كانت مقصد الحجاج من كل صوب وحدب، أثناء الحياة وبعد الممات ( رحلة حج رمزية ). فكانت الزوارق تشق عباب النيل لإدراك البركة من أوزير، جيئة وذهابا (26)

وتعددت مقامات أوزير في سائر أرجاء مصر لتصير نماذج أولى لمقامات القديسين ( المسيحيين)

$$
\text { والأولياء ( في الإسلام ) . }
$$

كما كان لأوزير زورقه المقدس الذي يستقله مع قاصديه من الحجيج، ولم يزل للأولياء ( المسلمين ) قواركم النيلية التي كانوا يستقلوها للتنقل مع مريديهم في ربوع مصر العظيمة. وإذا كان الإسلام - كما روى النبي - يجب ما قبله (من كفر) فإنه تعايش مع حضارات البلاد المفتوحة لتزدهر معه حضارة جديدة تجمع أشتاتا من التقاليد والفنون متعددة الأطياف .

\section{التمطيب والصراع الطقسي :}

لانتصار أوزير على ست منزلة كبيرة في المعتقد المصري القديم، الذي نؤمن أنه لا يزال يعيش في خواطر الناس، وكان يصور في ثمانية مشاهد ينطبق عليها وصف المسرحية، الأمر الذي يؤكد أن الدراما ظهر في مصر قبل أن تظهر في بلاد اليونان (27). إفا مسرحية آلام أوزير، وترجع إلى عهد الأسرة الثانية عشرة ( تحديدا سنوسرت الثالث ت 1841ق. م ) ونلخصها : في البداية يقوم وبواووت ( فاتح الطريق ) الركب، وهو رب يظهر في هيئة ابن أوي، ثم يظهر أوزير مبحرا في رفقة الحجيج، ليحتفل بانتصاره، ثم يقوم تحوت رب المعرفة بتمجيد جثثه، وبعد ذلك يحنط أوزير، ويدفن في قبره بالعرابة. وتقام شعائر الدفن، فتتحرك جنازة مهيبة تشق الصحراء، وفي الفصل السابع ينتصر أنصار أوزير على ست وأعوانه في " يوم العراك العظيم " الذي يتجلى فيه جمال الإله المنتصر، وذلك عند ماء " نديت " قرب العرابة أيضا .

وفي الفصل الثامن يبعث أوزير من جديد. أرأيت إذن كيف كان العراك يتم باستخدام العصي بين الفريقين ؟ أليس هو رقصة التحطيب المشهورة عندنا في الريف ؟ وإليك الآن - لمزيد من الدقة رواية هيردوت عن ذلك الصراع الطقسي بين أنصار الإلهين، الذي كان يحدث أيضا قرب سايس في الدلتا. يقول : " وعند ميل الشمس إلى الغروب تنصر قلة من الكهنة إلى الاهتمام بتمثال الإله، وتقف 
أكثريتهم مزودين بعصي من الخشب. بينما يحتشد عند مدخل المعبد وفي مواجهتهم جمع آخر من الرجال يربو عددهم على الألف، يوفون بالنذور وبأيديهم العصي أيضا .. وتحر الفئة القليلة معفة ذات أربع عجلات، تحمل المقصورة والتمثال الذي بداخلها. وبينما يمنعهم من الدخول الكهنة الذين يقفون عند المدخل، يتقدم الذين يوفون بالنذور لنجده الإله، ويضربوغم. فيدافع هؤلاء عن أنفسهم وعندئذ تنشب معركة حامية بالعصي، فتشج رؤوس بل يموت كثيرون - كما يخيل إلي - بسبب جراحهم. ولو

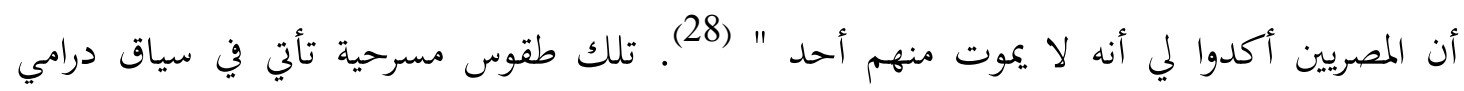
متكامل لاشك أنه ظل نموذجا يقوم المصريون بمحاكاته في موالدهم واحتفالاقم الشعبية التي تغير - عبر العصور - أبطاها، فأصبحوا من أولياء الله الصالحين وأهل الصوفية. والمطالع لمدائح الأولياء يقع كثيرا على تصويرات لحروب اشتبك فيها القنا، وجمحت الخيول، وصالت الفرسان .ويصعب علينا - والحالة هذه - تفسير ذلك إلا في إطار المعركة الكبرى التي تدور رحاها بين الخير وأتباعه من جهة، والشر

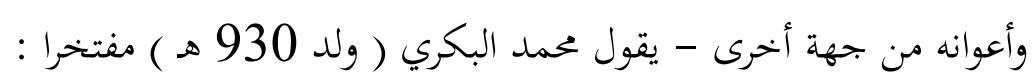

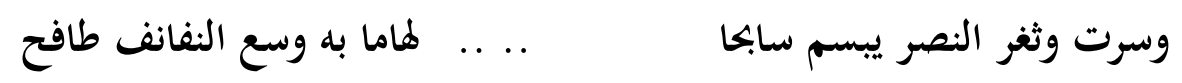
كأن مجر الجيش بالقوم زاخر

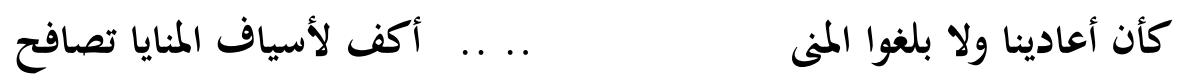
ونحن ملوك الحرب والصيد صدينا .. ... وليس لنا إلا الأسود جوارح(29) ذاك نموذج يذكرنا بفخريات الشريف الرضى ( ت 406 هـ ) وكان نقيب الأشراف الطالبين في

$$
\begin{aligned}
& \text { بغداد، وأشعر بني هاشم (30). وهو القائل : }
\end{aligned}
$$

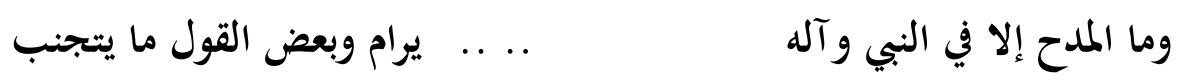

ونضيف باختصار أن أوزير قدم نموذج الراعي الصالح الذي يفدي البشر مضحيا بنفسها، ضارا 


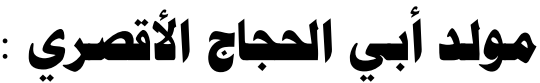

تقدم أن طيبة كانت المسرح الذي استقبل ذلك القادم من بغداد : أبا الحجاج ( ت 642 /

1244م ) ليستعيد ذكر آمون من جديد(31). كان شيخنا إذن معاصرا لابن عربي والسهروردي، وعلى لميل يدا الأخير تلقي مبادئ الفقه الشافعي. وفي مولده تظهر الأسرة الحجاجية في هوادجها، وقد اصطفت مواجهة لصرح معبد الأقصر ومسلته .

وأثناء الموكب تتلي الأهازيج في مديح الأقطاب كالسيدة نفسية، وسيدي المقشقش صاحب

المقام الشهير المحاور، وكان طبيبا راهبا دخل الإسلام، وصار مقصدا لطالبي البر، والشفاء (32). كما يشاد بالمرسي والبوصيري والقباري والجزولي والقناوي، والطواب إمام قوص .. " وأبو الحجاج دا جدنا وجديدنا .. والصابوني دا منجد المتضايق. وأبو العباس دا جدنا وجديدنا .. والشيخ طابع دا منجد المتضايق .. شفوا البلاد الأربعة الأقطاب .. ساكن المحر جدنا البغدادي. ساكن الأقصر يوسف أبو الحجاج. ساكن قوص شيخ أحمد الطواب. ساكن قنا بعد الرحيم يا قناوي (33). ونلاحظ أن كل مركز أو ناحية كان له وليه أسوة بأرباب الأقاليم المصرية القديمة، إذ كان لكل إقليم في مصر ربه المحلي. ويبدأ التجهيز للمآدب قبل المولد بأسبوعين، ويعد خصيصا الثريد الكباب (كرات مكببة من اللحم الأحمر مخلوطا بالبصل والقمح المدشوش) وكان أبو الحجاج يقدمه لضيوفه ومريديه. وأما القارب. وقد تقدم الحديث عنه - فقد كان صلة بين الشيخ ومريديه، وكذلك كان قارب آمون، يستخدمه لزيارة المرضى والمقعدين، والمعوزين الذين قعدت بهم الحاجة عن المشاركة في الاحتفال، فإذا بصاحب الاحتفال

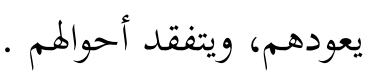

كذلك يجب أن تكون علاقة الأعلى بالأدن. أليس ذلك درسا في السياسة أيضا ؟ (34) ليست الزعامة ( السياسية ) تعاليا بل هي تواضع .كذلك كان محمد بن عبد الله، الذي روى عنه : لا

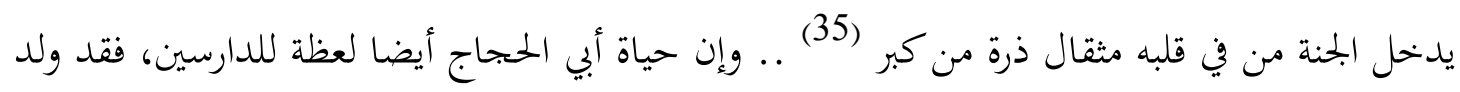
في بغداد سنة 531هـ / 1136م، وظل بها حتى سنة 555هـ / 1160م، وتلقى الفقه الشافعي على يدي السهروردي (36) 
واضطر لمغادرة بغداد لما عاناه السنة من تضييق. فرحل إلى مكة طالبا العلم، وكان يعمل بغزل الصوف وحياكته .. ويرقى شيخنا بنسبه إلى الإمام علي بن أبي طالب كرم الله وجهه (37). وهذا شأن أئمة التصوف جميعا فيما نعلم. فأبو الحجاج إذن مثل أعلى للفتوة كما كان على . كذلك قدمنا قصة زواجه من ترزة بنت القيصر التي أعلنت إسلامها على يديه لما رأت من كراماته، وقد تنبأت لها النبوةة بذلك، على نحو ما بنحه في الأدب الشعبي منذ نبوءة عرافة معبد دلقي عند اليونان (38). هكذا كان الصوفي يتكسب من عمل يديه، ويمرص على طلب العلم، وكان اعتكافه ذكرا لله وزهدا فيما في أيدي الناس(39)

\section{هن كراهات الأقصري : من}

الكرامات أفعال خارقة للعادة تنسب إلى الأولياء. ومما قاله الغزالي فيها : " لو رأيت شيخا يطير في الهواء، أو يمشي على البحر، أو يأكل النار أو غير ذلك وهو يترك فرضا من فرائض الله أو سنة

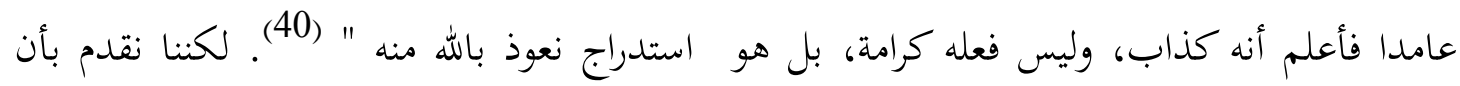
المصري منذ القدم قد ألف الحوارق والإيمان بالسحر، فقد كانت إيزيس هي عظيمة السحر ( ورت حكاو )

ولا غرو أن يؤمن العوام بالتمائم والأحجية، والقدرات الغيبية للمشايخ والأولياء، تلك التي تتجاوز مألوف قدرات البشر، وقد كان المصريون يتداوون على يد القديس مرقس ومريديه بأيقونات السيدة العذراء ( مري ) (41) .. وعلى نحو مشابه كان القوم في التاي وآسيا الوسطى والغربية يعتقدون في قدرة الحكيم ( شامان ) على الاتصال بالحقيقة العليا، وإقامة علاقة مع الأرواح والتأثير عليها، ونفي الحبيث منها، فيشفي حينئذ من تباريح الأمراض، وبقى من الشرور ل... الخ (42) . ولعل اعتقاد العامة في كرامات الصوفية يدخل في هذا الباب أيضا فللمتصوفة قدرات أرقى من ترن قدرات البشر المعتادة، وذلك أفم عارفون بالله قريبون من الحقيقة. ويروي عن الأقصري كرامات منها رؤية النبي ولقاؤه الخضر، فقد كان الأقصري في طريق زيارته للسيد الفنائي، فلقى الخضر، وسأله النصيحة، فحضه على تقوى الله في السر والعلن، وحذره من الرياء وعدم البكاء على ما فاته من الدنيا

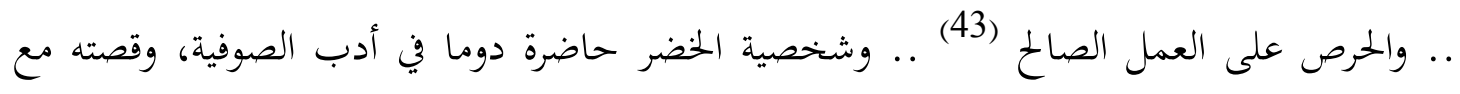


النبي موسى عليهما السلام مروية في القرآن ( الكهف : 67 - 82 )، وقد استشهد بها الصوفية في أشعارهم على نخو ما فعل ابن الفارض ( ت 1234م ) في تأتيته الشهيرة إذ قال : قتلت غلام النفس بعد إقامتي ال .. .. جدار لأحكامي وخرق سفينتي ( ديوان ابن الفارض : ط. صادر، بيروت، 112 )، وأما جوته ( ت 1832 ) فقال في ديوانه الشرقي : " سيعيد ينبوع الخضر شابا من جديد " (44) .

\section{هولد السيد أحمد البدوي : ( 596 هـ / 1200م ) :}

تكاد تقترن طنطا - في المخيلة الشعبية - بذلك الفارس المثلم أ، ذي اللثامين الذي قدم من فاس بالمغرب بعيد موقعه حطين أي في عصر الصدام والحروب الصليبية والتهديد المغولي. ولعل ازدهار طنطا ( طندتا ) التجاري يعزي - ضمن أسباب أخرى - إلى مقام البدوي، الذي يعد محجا تهوي إليه القلوب من كل صوب وحدب. بل إن مؤرخنا الكبير سعيد عاشور يروي أن بعض المريدين بالغوا فحدثوا عن زوار يأتون من الهند وأقاصي آسيا ليرفعوا من شأن ذلك الولي (45) بردئ ويروي علي مبارك أنه اتفق أن البدوي توفي ثاني عشر ربيع الأول، ولعل ذلك من كراماته أيضا،

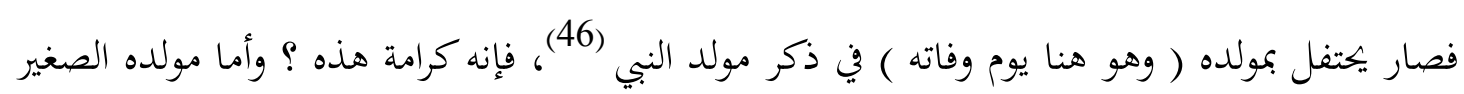
فعرف بالمولد الشرنبلابي، وذلك أنه حضر لزيارة مقام أستاذه في غير موعد مولده، فصار بزيارته سنويا. وأما المولد الثالث للبدوي، فهو المولد الرجبي نسبة إلى الشيخ الرجبي الأحمدي الذي زاره لتجديد عمامته، لذا يعرف بمولد لف العمامة، وبلغت محبة البدوي شأوا كبيرا حتى صار الاحتفال بمولده الكبير يدوم نخو ثلاثة أسابيع أحيانا بحيث يوافق ختامة ليلة الثاني عشر من ربيع أول (47.) وكان أوليا جلبي كمن وصف مول البدوي وغيره من أولياء الله حينما زار مصر في القرن السابع عشر . 


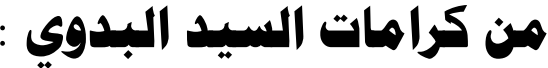

عرف شيخنا بذي اللثامين لقوة نوره وجهه التي يتوجب الوقاية منها ! وروى عن إحيائه الموتى، فقد سألثه امرأة أن يرد صغيرها المتوفي، فأحياه لها الله ببركة الشيخ وبركة جده عليه الصلاة والسلام. كذلك أمات البدوي جمال فاطمة بنت برى، وكانت عدةما سبعة آلاف ثم أحياها - بأمر الله - في طرفة عين (48.) والاحتكام إلى المنطق في مثل هذه الأمور ليس في صالح أرباب الكرامات .

\section{المولد وأدب السيرة : المبرة}

نسجت البطولات الأسطورية حول أبطال السير والمغازي مثل ذات الممة والبدوي والشاذي،

وسيف والظاهر .. الخ. السيرة إذن قد تكون لبطل شعبي أو ولي صوفي أو قائد سياسي أو عظيم ما. وأول الأبطال وعظيمهم هو محمد عليه السلام، الذي بشرت بمقدمة سيرة عنترة العبسبي، وسيرة سيف بن ذي يزن. إذ سأل عبد المطلب هبل عن الرجل الصالح القادم : متى يأتي ؟ فرد هبل : " لما أينع النخل في يثرب وحل الجوع والغلاء في المغرب. لما تمدم إيوان كسرى ..لما علق علي الكعبة قصيدته

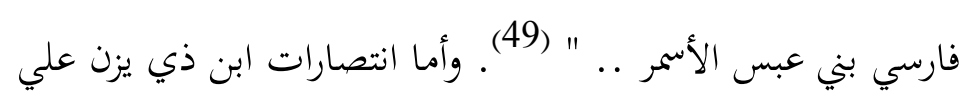

الأحباش، وهو سليل ملوك حمير ،الذي يوحد العرب، فكانت إرهاصا بمجئ محمد (50).

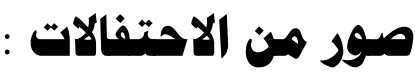

للموالد منطقها الحيوي الذي يعبر عن روح الشعب كما تقدم. ففي موالد القاهرة حسب

وصف علي مبارك " تروج البضائع سيما الحلوى والحمص والفول والترمس والفستق، وأصناف المأكولات، ويتنفع بعض الفقراء وطوائف الشعوذة، كالحواة وخيال الظل والمراجحية .. وتنال خدمة الأضرحة من النذور والصدقات أضعافا .. إن المحاورين لمحل المولد يعملون وقدات وختمات وأذكارا وولائم .. وفيي الموالد الكبيرة مثل مولد النبي والحسين والشافعي تكثر الحركة .. وتتسع دائرة اكتساب الخدمة .. وتكثر الولائم والوقدات (51)

وصف دال على أن المولد ظاهرة مركبة متسعة، ذات امتداد زماني إذ تعبر عن عادات أصيلة، ومكاني إذ يلتقي في المولد أناس من شتى الاتحاهات. المولد إذن معرض حي لفنان هو الشعب بأسره، وساحته ممتدة في الزمان والمكان. أما جومار -من عصر بونابرت - فيصف مولد السيدة زينب حفيدة 
الرسول، فيذكر حملة المشاعل ( المشاعلية ) على رأس الموكب ثم المغنين والعازفين وحملة المصابيح ( في أشكال هرمية ). وأما الدكاكين فتظل مفتوحة وقد زينت بفوانيس ورقية كثيرة. " ويكتفل بمولد السيدة أيضا بأنوار الزينة الكبيرة. ففي اليوم الأول، في التاسعة مساء يتحرك الموكب في مقدمته أفراد يحملون المشاعل - عبارة عن أقفاص من حديد تحرف فيها أخشاب صمغية، ثم يأتي المغنون والآلاتية على برتي دفعات متتالية .. يتبعهم ستون إلى ثمانين رجلا يحملون أهرما من المصابيح، ويختلط بهم رجال تقاة .. ينشدون الابتهالات الدينية، وفي فاية الموكب يأتي اثنا عشر رجلا متشحين بالبياض ثم يختم شخي

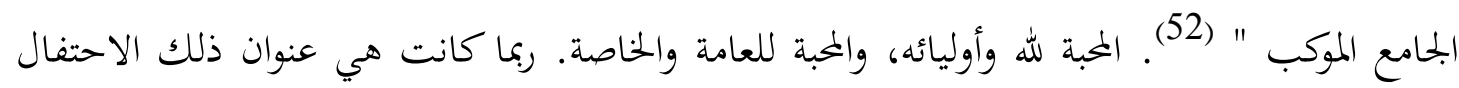
الشعبي الخالد المسمى بالمولد. ومقصدنا الآن أن نعرف باحتفال شيعي قريب من المولد، وهو المأتم أو التعزية، وفيه عناصر درامية ربما كانت أوضح مما في المولد .

\section{المأتم ( التمعزية ) :}

كان لاستشهاد الحسين رضي الله عنه في كربلاء أثره في نفوس المسلمين لاسيما الشيعة، الذي دأبوا على الاحتفال به ( ذكرى عاشوراء ) والصلة قوية بين المأتم ومسرحية آلام أوزير كما ترى فايزة هيكل (53). وقد وقفنا على بعض أوجه الشبه بين موالدنا الحالية ومسرحية أوزير. بيد أن المأتم الشيعي عمل تمثيلي درامي، ومشاهدة الرئيسية هي : ما قبل كربلاء، وتحكي عن فاطمة بنت محمد وعلي، تم

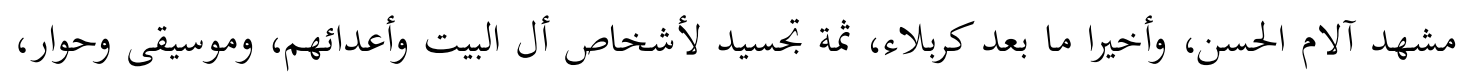
وإنشاء ديني، وتمة جوقة تنشد وتردد (54). نرى مشهد وفاة فاطمة، وزوجها علي يجري معها حوارا حزينا، وفي مشهد آخر يقوم المداحون ( روزي كان ) من شيعة إيران بتلاوة المديح والرثاء في الحسين، ويؤازرهم الندابون ( نوح كان ) يندبون ويعددون، ويتجاوبون مع الروزي كان. والبعض ينسبون طقوس العويل والندب إلى ما كان يجري في عبادة أدونيس - تموز، وقد يصح هذا. ولكن الأولى الرجوع إلى طقوس أوزير، فهو نموذج الشهيد

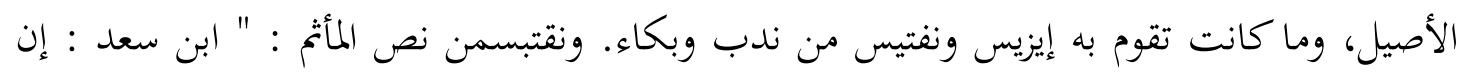
كراهيتك العمياء تفقدك الصواب .. شمر : سأقتل الحسين بنفسي. " (55). ولكن موقف القتل ذاته يتحاشى (كما في دراما آلام أوزير المصرية ) . 
وقد ولع شعراء بصياغة ملاحكم وحكايات دينية، منها قصيدة في وصف الدلدل، وهو المطية

التي ورثها على عن محمد. يقول سليمان تيماني من خلوتيه القرن 18م : " حين يمتطي على الدليل ..

تلع قلوب الكفار من الرعب. أنت صاحب ذي الفقار الذي يحتقر كل مذكر، ويقطع كل كافر " (56). ويصور الدلدل بغلة بيضاء. أما ملحمة كربلاء فقد استلهمها نعيم فراشري الشاعر الألباني، فنظمها شعرا منذ سنة 1892 في عشرة آلاف بيت. قال : " يا الله، لأجل كربلاء. لأجل الحسن والحسن .. والأيمة الاثنى عشر .. لا تدع ألبانيا تسقط أو تتمزق .. لتبق خالدة .. ليبق الألباني بطلا

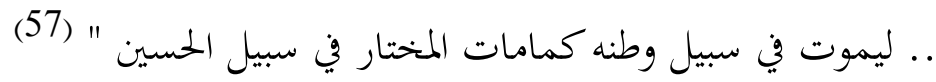




\section{المولد في الأدب}

\section{المدائح النبـوية والمولد}

عرف العرب منذ جاهليتهم مديح الملوك والعظماء .. ولم يكن شعر العرب كله مديها، ولم يكن شعر العرب كله مديحا. ولم يكن المديح كله رخيصا ولا أجوف. فكان زهير بن أبي سلمي حكيم الجاهلية وصاحب المعلقة الثالثة لا يمدح الرجل إلا بما فيه كما قال عنه عمر بن الخطاب رضي الله عنه (58)

وقد تقدم أن ثمة إشارة إلى مقدم محمد وبعثنه في سيرة عنترة العبسي، وهو صاحب المعلقة السادسة، الذي ود الرسول صلى الله عليه وسلم لو قابله فيما يروى عنه، وذلك لسماحته وبحدته وكرم

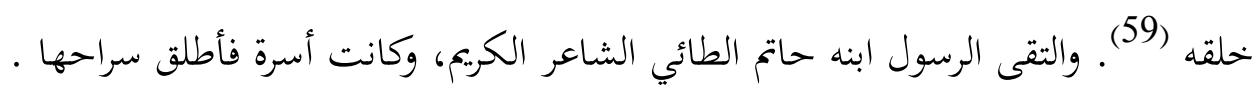
وقد شاءت الأقدار أن يلتقي الرسول بابني زهير : كعب وبير : على نو ما سنوضحه توا. وسيكون كعب صاحب البردة الشهيرة في مديح الرسول، والمؤسس الحقيقي لفن المدائح النبوية، وإن كان الأعشى ميمون بن قيس ( ت 629م ) قد سبق كعبا، وذلك إن صحت نسبة دالتيه إليه، ومطلعها :

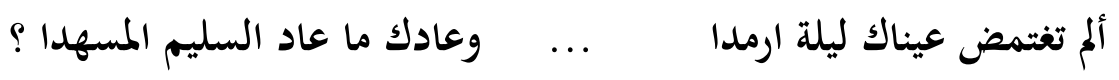
كذا نسبت لأبي طالب عبد مناف بن عبد المطلب غير قصيدة في مدح الرسول، ثم عرفت

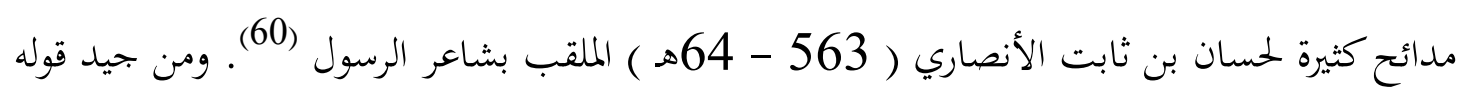
في محمد :

كأنك قد خلقت كما تشاء

$$
\begin{aligned}
& \text { وقصيدته الشهيرة التي مطلعها : } \\
& \text { إن الذوائب من فهر وإخوتم بينوا سنة للناس تتبع }
\end{aligned}
$$


من يرد دليالا على حلم الرسول، وكيف تتبدل به المواقف إلى النقيض فلينظر في قصته مع كعب، فقد تأمر ليقتل محمد، فأبيح دمه حتى بجير أخاه أن يذهب إلى محمد طالبا العفو، لأنه يقتل من جاء معتذرا. فذهب وأنشده :

م إثيم إثرها لم يفد مكبول وعرض بالوشاة، واستعطف الرسول ومدحه، فقال :
تسعى الوشاة بجنبيها وقولمم إلى قوله : لا تأخذني بأقوال الوشاة ولم ...أظلم ولو كثرت عني الأقاويل إن الرسول لنور يستضاء به مهند من سيوف الله مسئول فإذا بالرسول يحسن استقباله، والإصغاء إليه حتى إذا فرغ من قصيدته كافأه ببردته، ولذلك ستك

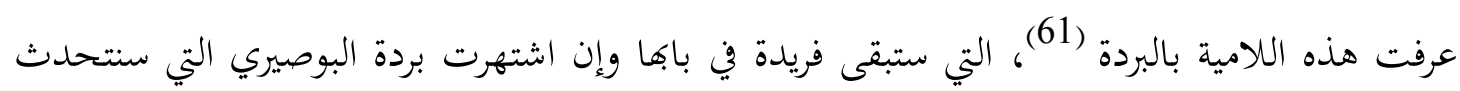
عنها الآن . ع

\section{البـوصيري ( 608 - 696 هـ ) :}

كان أحد أبويه من دلاص والآخر من بوصير، وهما من أعمال بني سويف، فعرف بالدلاصيري أو البوصيري ( الأباصيري ). وقد وسد ثري الإسكندرية بجوار ضريح معلمه المرسي أبي العباس الذي كان بدوره من مريدي أبي الحسن الشاذلي ( ت 1258 م ) (62). وللبوصيري على الأقل عشر الإسريح قصائدة طويلة في مديح الرسول، ولكن بردته ( الميمية ) ذاعت شهرتا، فصارت تتلى في الموالد والحضرات الصوفية تقربا إلى الله تعالى .ولما كان زمان البوصيري قد شهد فصلا من فصول الصدام بين الغرب والشرق، فقد جند شاعرنا قلمه للدفاع عن الإسلام ورسوله ووطنه ضد الغزاة الصليبين، منتقدا سنة الجائرين من الحكام. ومن مدحياته الشهيرة الممزية (63) :

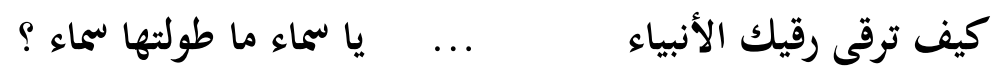




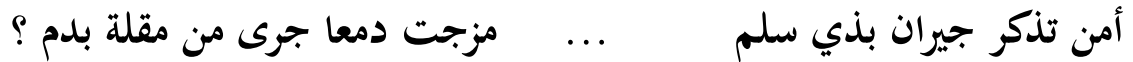

وهي على وزن ميمية ابن الفارض وروريها، وكلتاهما في معارضة ميمية كعب بن زهير. ولبردة البوصيري قصة. يقول : " أصابني فالج أبطل نصفي ،ففكرت فيعمل قصيدتي هذه، فعملتها، واستشفت يما إلى الله تعالي .. وكررت إنشاؤها .

ودعوت وتوسلت وتمت ،فرأيت النبي صلى الله عليه وسلم. فمسح وجهي بيده المباركة، وأللقي

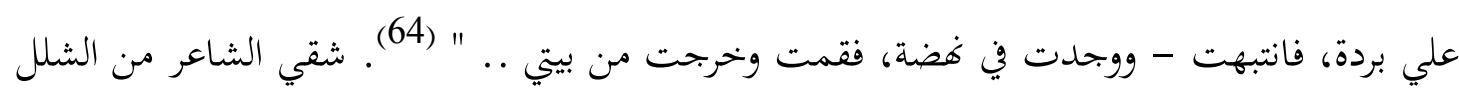
إذن في الحلم قبل أن يشفى في الواقع، من النقاد من أنكر الواقعة بل أنكر المرض ذاته، ومنهم من قبل. وتلك القصة من المرويات الشعبية التي نرى أن الاعتقاد فيها لا يضر. ولا يجوز أن نختكم إلى العقل في مثل هذه الأشياء، فليقبلها من شاء أو ليرفضها (65). وقد أشار بعض الشعراء إلى أهم رأوا الرسول. قال البارودي في ملحمته النبوية : "كشف الغمة في مدح سيد الأمة : حبي بطلعته الغراء مفخرة لما التقيت به في عالم الحلم وقد حباني عصاه فاعتصمت بما . فيكل هول فلم أفزع ولم أهم

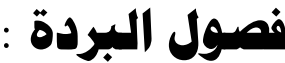

فصلها الأنصاري وهي : الغزل وشكوى الهوى، والتحذير من هوى النفس، وفي مديح النبي، ومولده عليه السلام، وفي معجزاته، وفي شرف القرآن ومدحه، وفي حدث الإسراء والمعراج، وفي جهاد النبي وحروبه، وفي التوسل برسول الله ثم في المناجاة وعرض الحاجات (66). وهذا الترتيب الحر أتاح للبوصيري حرية أكثر في الإبداع فيما التزام البارودي سيرة الرسول كما رواها ابن هشام(67). يقول

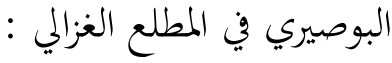
أمن تذكر جيران بذي سلم مزجت دمعا جرى من مقلة بلدم ؟ أم هبت الريح من تلقاء كاظمة ...أومض البرق في الظلماء من إضم ؟

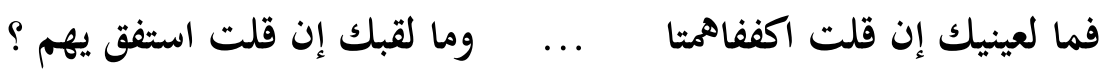
أيحسب اصب أن الحب منكتم ..ابين منسجم منه ومضطرم 


$$
\text { ولولا الوى لمتزق دمعا على طل ...ولا ارقت لذرك البان والعلم }
$$

نلمس صدق عاطفة الشاعر، إذ يذكر معاهد الأحبة هناك حيث ولد محمد، وربما زاده شوقا

إليها بعد المسافة. ويجري حوارا مع من يلومه في حب آل البيت - على سبيل المحاز المرسل - متشبها

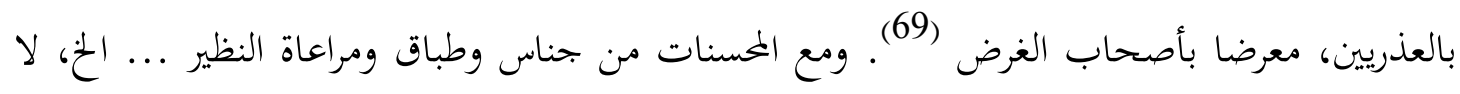
تلمس أي تكلف أو تعسف .

نعم الاستهلاك ذلك. ونيل إلى مطلع ميمية ابن الفارض لنتيح للقارئ الكريم بعض المقارنة. يقول (69) :

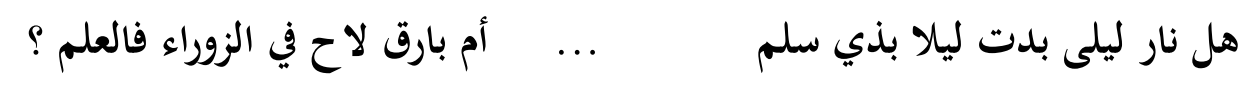

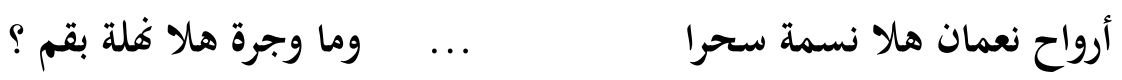

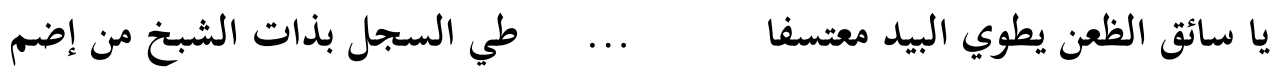

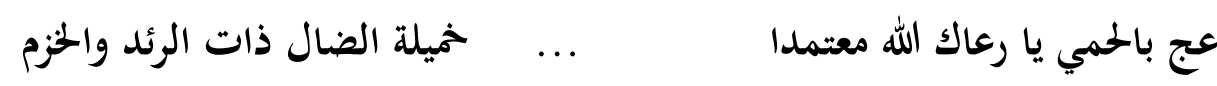
وقف بالحمي يا رعاك الله معتمدا بالرقمتين أثيلات بمنسجم ؟

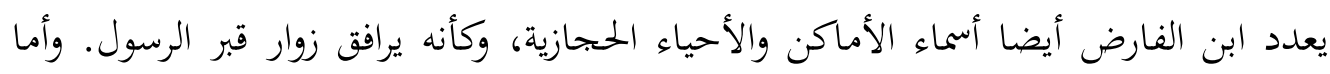
حديث الظعن أي الارتحال فيذكرنا بالمطلع الغزلي الجاهلي، وبأن الدنيا دار رحيل وهي أشبه بالصحراء القاحلة التي لا يجملها إلا ذكر الأحبة. وأما مطلع البارودي فيركز على خاطرة طريقة، وهي إحياء الأطلال الخمبوبة بالقطر حتى تبدو من أجل حلة خضراء زاهية (70) : يا رائد البرق يمم دارة اعلم احد الغمام إلى حي بذي سلم وإن مررت على الروحاء فامر لها ..أخلاف سارية هتاتة الديم

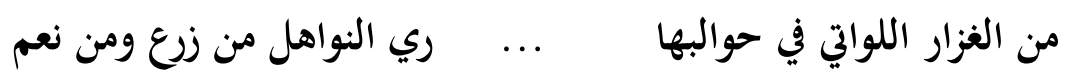
إذا استهلت بأرض نمنمت يدها ..بردا من النور يكسو عاري الأكم ترى النبات بها خضرا سنابله . . يختال في حلة مشيه العلم . وقد يظن أن أوربا القرون الوسطى لم تعرف الغزل الرفيع هذا، بل ظهر شعراء الغزل العفيف في بلاط الإمبراطور فردريك فون هوهنشتاوفن ( ت 1250م ) في بالرمو (71) على سبيل المثال .. 


\section{الإسراء والمعراج}

يؤمن المسلم بحدث الإسراء والمعراج، وإن كان ما ورد في شأنه من روايات محل اختلاف بين علماء الفقه والحديث (72). وطبيعي أن يتسع خيال الشاعر لروايات فرعية وتفاصيل لم يرد بشأفها أحاديث مؤكدة. والجميل أن البوصيري تخيل موكب الرسول الكريم كأنه يراه رأي العين فيصفه قائلا : يا خير من يمم العافون ساحته .يعيا وفوق متون الأينق الرسم سريت من حرم ليلا إلى حرم كما سرى البدر في داج من الظلم

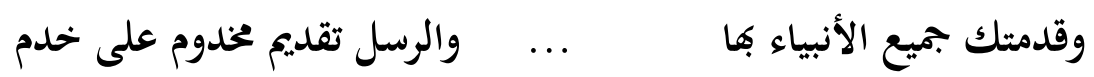
وأنت تختزق السبع الطباق بمم ...في موكب كنت فيه صاحب العلم

استخدم في سراء فعل سري ( من الإسراء أي السفر ليلا )، وشبه الرسول الكريم بالبدر في سراه، وصور موكب الرسل وعلى رأسه محمد، وأن لم يوفق في قوله، مخدوم على خدم " في شأن الأنبياء الكرام، وصور صعودهم في أجواز السموات العلا .. ومن حق الشاعر أن يطلق لخياله العنان في مثل

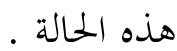

وأما قوله الذي يكرره المنشدون كثيرا أثناء تلاوة القصيدة : مولاي صل وسلم دائما أبدا ...على حبيبك خير الحلق كلهم فيعتمد على قوله : " إن الله وملائكته يصلون على النبي يا أيها الذين آمنوا صلوا عليه وسلموا

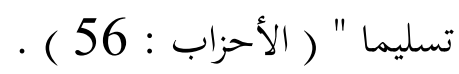

ويقودنا الحديث إلى " المعراج " الفارسي، وهو فن عظيم الشأن ،ومن رواده فريد الدين العطار ( قتله المغول سنة 627هـ )، في معراجه المسمى " مصيبتنامه " فهمي معراج يقطع فيه المريد بقيادة المرشد أربعين مرحلة تشمل كل مقامات الصوفية وأحوالهم وعوالم الملائكة والكواكب والأفلاك ". ولا غرو أن يكون لكل من أولياء الله كإبراهيم الدسوقي مثلا معراجه الخاص به. ويكفينا القول إن المعراج أدب سام عظيم ( خاصة عبد الفرس )، وقد كان له أثره في " الكوميديا الإلهية " لدانتي شاعر إيطاليا الشهير. وقد أفاض تشير ولي وبالاثيوس وغيرهما في الحديث عن ذلك (73). أما البارودي فيتوقف مليا عند مشهد اختباء الرسول وصاحبه بالغار : " إلا تنصروه فقد نصره الله إذ أخرجه الذين كفروا ثاني اثنين 
إذ هما في الغار .. " ( التوبة :40 ). فيصور شاعرنا زوج الحمائم وبيت العنكبوت الذي نسجه على فم الغار، فبدا وكأنه خيمة " حكاها لبق بأرض سابورفي بحبوحة العجم ". قال واصفا :

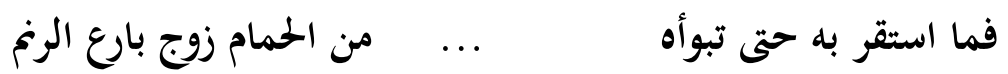
بني به عشه واحتله سكنا يأوي إليه غداة الريح والرهم إلفان ما جمع المقدار بينهما إلا لسر بصدر الغار مكنتم والمقطع طويل، ويعد من أرق الشعر وأعذبه، إذ يظهر زوج الحمائم حارسا أمينا، وقد جمع الغرام بينهما، وأراد القدر أن يلتقيا لحماية من بالغار، كما وصف الشاعر هذين الطائرين في السكون والحركة، وعزا احمرار قدم الحمامة إلى أها خاضت في دمعه الذي يشبه الدم القاني، لينقلنا إلى جو منفاه الأسى، وفي بعض الوصف نشعر بحال الدعة والهناءة التي لا يحس بها إلا الطائر (74). ونعاود البردة لنقف على مواضع التشابه والالتقاء بين الشاعرين. كما قول البوصيري :

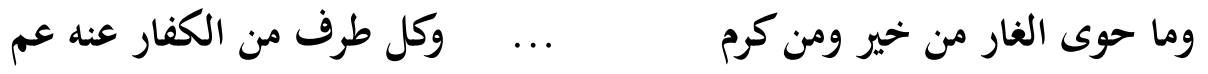

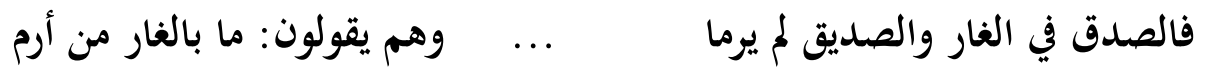

$$
\begin{aligned}
& \text { ظنوا الحمام وظنوا العنكبوت علي ... خير البرية لم تنسج ولم تحم }
\end{aligned}
$$

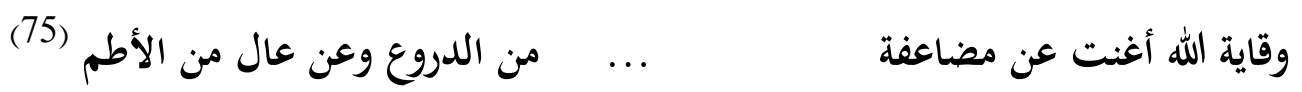
وذلك وصف جميل، فالغار مشتمل على الخير والكرم والصدق ومعه الصديق أبو بكر. ووقاية الله أقوى من الدروع والقلاع ( الأطم ). ويتلاعب البوصيري بالألفاظ : لم يرما، من إرم ( إنسان ) . فإذا رجعنا إلى البارودي وجدناه يصف العنكبوت وقد صنع خيمة بديعة مشدودة الأطناب كأها من صنع سابور المشهورة بصنع السجاد. مبالغة حببها إلى السمع جمال التصوير. وكم من

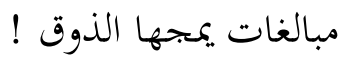




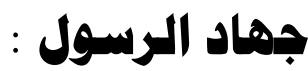

أبدع البوصيري في وصف جهاد الرسول وصحبه، وإن كنانرى أن البارودي أفاض في وصف

الحروب التي خاضها، فجاء وصفه كأنه يعيشها. اهتم البوصيري بثبات الصحابة وفدائيتهم : وواضح أنه لا يسترسل في وصف الحروب مكتفياً بذكر أسماء الغزوات ولكن فن وصف الحرب بخده مكتملا عند الباروي. وتأمل في الأوصاف التالية بتحها شكلية بعض الشيء. يقول البوصيري مستكملا.

شاكي السلاح لهم سيما تيزهم ..والورد يمتاز بالسيما من السلم تقدي إليك رياح النصر نشرهم ..فتحسب الزهر في الأكمام كل كمى كأفم في ظهور الحيل نبت ربا ... من شدة الحزم لا من شدة الحزم

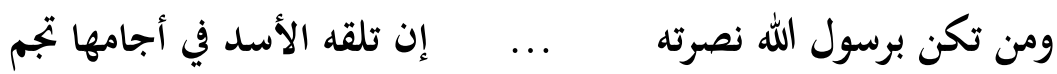

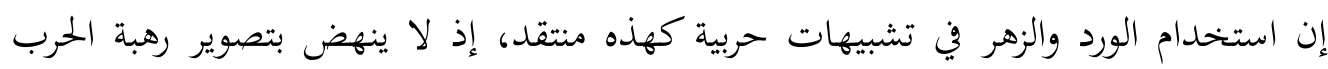
وفتكها. ومع حسن تقسيم العبارة يولع البوصيري بالحسنات ( الجناس : سيما، سيما وشدة وشدة، أكمام وكمي .. أجامهم بتم ... إلخ ). وهو أقل سماجة من سجع نظام البديعيات، وأقل تكلفاً من

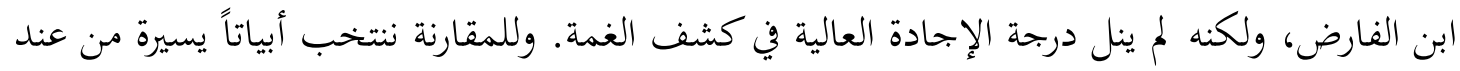

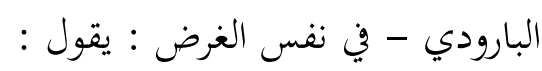

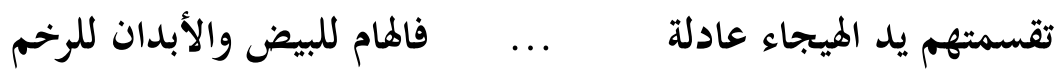
كأثما البيض في الأيدي صوالجة ...يلعن في ساحة الهيجاء بالقمم

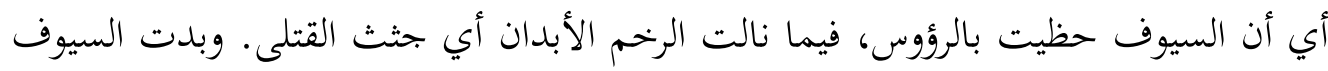

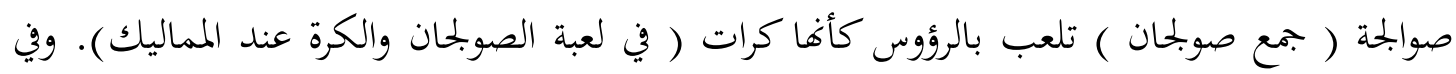
أبيات أخرى يستبطن البارودي حال الهزيكة بعد الزهو والخيلاء، فيقول مبكتاً الكفار : فأين ما كان من زهو ومن صلف ... وأين ما كان من فخر ومن شتمم؟ جاءوا وللشر وسم في معاطسهم ... فأرعغموا والردي في هذه السيم من عارض الحق لم تسلم مقاتله ...ومن تعرض للأخطار لم ينم 
الاستفهام الإنكاري بليغ يشي بحال الهزيمة المخزية، والفخر الضمني. والبيت الثاني يشرح

ويفضل ما جاء في البيت الأول، ليستخلص الحكمة في البيت الثالث في تصعيد متقن. أما المحسنات فيحسن توظيفها قائلا في الصحابة على نو ما فعل البوصيري. يقول : من كل معتزم، بالصبر محتزم ... للقرن ملتزم، في البأس مهتزم

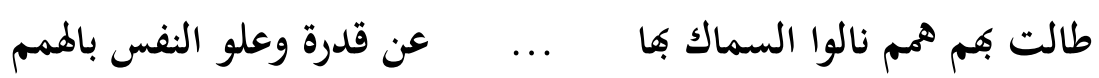

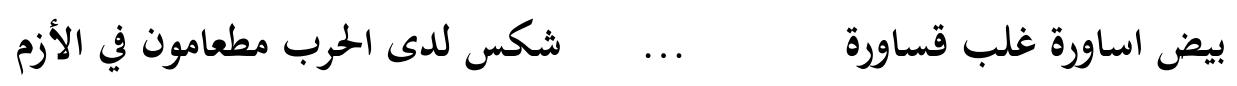

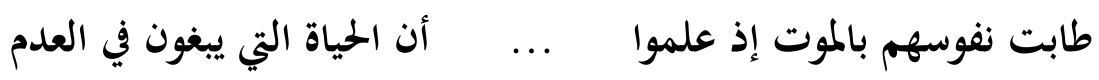
فجانس في البيت الأول أربعا، متبعا التقسيم الرباعي للبيت إعلاء للجرس. ثم عاد للجناس في البيت الثالث، وفي : طالت وطابت. إنه جناس ظاهر لكنه غير متكلف إذ يخدم العبارة والمعنى . وهذه المجموعة تشف عن نفس قائلها ذي الممة العالية كما يظهر في فخرياته الكثيرة، وعن تمكن البارودي من فنون القول .

وأما شوقي في " هج البرودة " فوصف الحرب وصفا فيه رقة لا تلائم جو الحرب العباس، وما تقضي به الحرب من غلبة الغضب وشمول العبوس على حد قول زكي مبارك (76) .. اسمعه يقول :

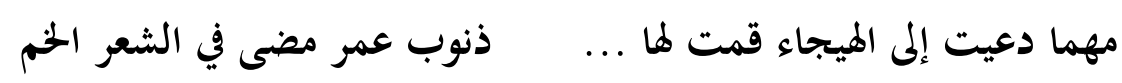
على لو أنك منهم، كل منتقم ...لاله مستقتل في الله، معتزم

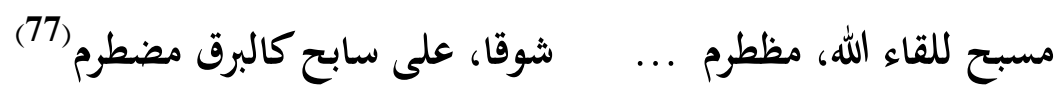
فالنبي يرمي بجنوده الشجعان كالأسود، والله يرجمهم كالشيطان، وقد انضووا كلهم تحت لوانه، واضطرموا شوقا على جيادهم، تلك التي تضطرم أيضا كالبرق .

التهوسل :

من أهم الأغرض في البردة، وقد شاعت على ألسنة الشعراء في العصر المملوكي العثماني

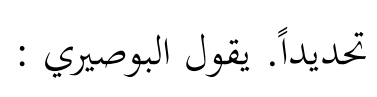

خحدمته بمديح أستقيل به

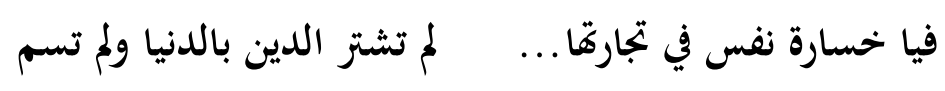




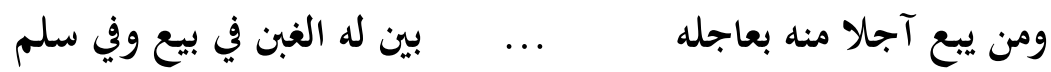

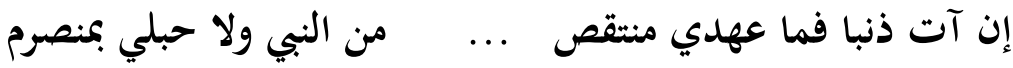

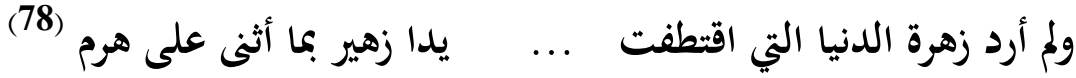

والأخيلة مستقاة من عالم التجارة والتسوق على نحو ما بجده في القرآن والحديث، ولكن ضرب

المثل بزهير فيه نظر لأن زهيراً لم يكن يطلب المال والدنيا بل حقن الدماء بين المتحاربين . والبارودي بلا شك نظر في البردة ساعة قالة :

خدمته بمديكي فاعتلوت علي هام السماك وصار السعد من خدمي وكيف أرهب ضيما بعد خدمتل . وخادم السادة الأجواد لم يضم

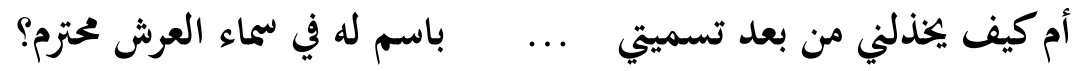

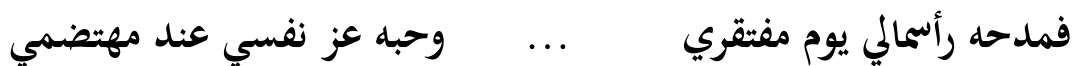

والسياق ينم عن فخر البارودي بنفسه ( اعتلوت على هام ... ) وتثته في الرسول : الاستفهام

الإنكاري في البيت الثاني والثالث، وأما " رأسمالي " و " عز نفسي " المساوقة لها فمن إق=تقان القول الذي تستحبه الأذن. وهذه من المرات القليلة التي يفخر فيها البارودي بكونه خادماً - بلي، خحادما للسادة الأجواد، كما يفخر بفقره حيث مديح الرسول يغنيه، فأي غني هذا ؟ ... كل تلك المعاني تعكس لنا صورة البارودي صادقة، فهو فارس لا يتعالى ولا يتكبر، ولكن يشيد بالفضل والفضائل (79).

أنقذ البوصيري فن المديح النبوي وحرره من قيد المحاكاة السطحية والتقليد، ولكن سرعان ما ظهرت البديعيات منذ القرن الرابع عشر الميلادي، والبديعية تلتزم بحر " البردة " وقافيتها الميمة، ويشتمل كل بيت فيها على نوع بديعي أو أكثر، والغالب أن صفي الدين الحلي ( 1278 - 1349) هو صاحب أول بديعية، وإن كان الأمر موضع خلاف (80). وقد أحصى نهو مائة بديعية ن منها اثنتان للشيخ عبد الغني النابلسي ( 1050 - 1143 هـ) صاحب رحلة مصر والشام والحجاز (81.) ومنها بديعية في مدع عيسى عليه السلام. نظمها إبراهيم خيكي الحلبي، التي قال في ختامها : من فبز بر حسابي يوم محتكمي ... أرجو الحلاص وأعطي حسن مختتم وللشيخ نصايف اليازجي بديعية ختامها : 
بئس الحياة التي طابت أوالها ... إن لم يكن طاب منها حسن غختتم

ولمحمود صفوت الساعاتي - الذي عاصره البارودي - بديعية متكلفة ... وهكذا دواليك. واللافت أن الحلي روى إصابته بالفالج أيضا كما حدث للبوصيري وشفاءه منه. وفيما يلي نورد استهلال بعضها. قال ابن جابر الأندلسي (82) : بطيبة انزل وحيي سيد الأمم ... وانشر له المدح وانثر طيب الكلم وذلك مطلع الحلة السيرا، وطيبة هي مكة. وأما الموصلي فقال : ( براعتي ) تستهل الدمع في العلم ... قد ( استهلت ) دموع العين كالعنم

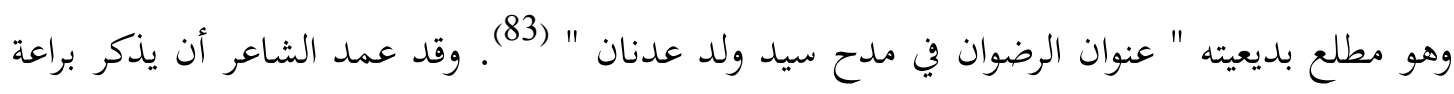
الاستهلال هنا وحسن المختتم هناك لأن كليهما من المسحنات البديعية . ومن المحسنات المبالغة. قال فيها أبن جابر الأندلسي : " أن يبالغ في المدح وغيره إلى مبلغ بعيد حتى يتوهم السامع أن الموصوف فيها وصفته به غير بالغ إلى غايته " (84 ويسمى هذا التبليغ، ومنها الإغراق والغلوم، وقد جمعها في أبيات :

$$
\begin{aligned}
& \text { يمم نبيا تباري الريح أنمله ... والمزن من كل هامي الودق مرتكم } \\
& \text { لو قابل الشهب ليلاً في مطلعها ... خرت حياء، وأبدت بر محترم } \\
& \text { تكاد تشهد أن الله أرسله ... إلى الورى نطف الأبناء في الرحم } \\
& \text { لو عامت الفلك فيما فاض من يده ... لم تلق أعظم بحراً منه إن تعم } \\
& \text { تحيط كفاه بالبحر الخيط فلذ ..به ودع كل طامي الموج ملتطم }
\end{aligned}
$$

تلك والله مهارة أشبه بمهارة لاعب الأكروبات، وكان ذلك العصر مما ازدهرت فيه فنون البهلوانات والمشي على الحبال ازدهارا منقطع النظير، فلم لا يتأثر بها الشعر أيضا ؟ قيمة هؤلاء الشعراء ( البديعيين ) أفم يظهرون لنا حقيقة إبداع شاعر قال هذه الأبيات :

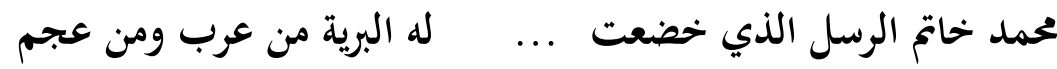
سمير وحي، وبجني حكمة، وندى ... لسماحة، وقرى عاف، وري ظم 


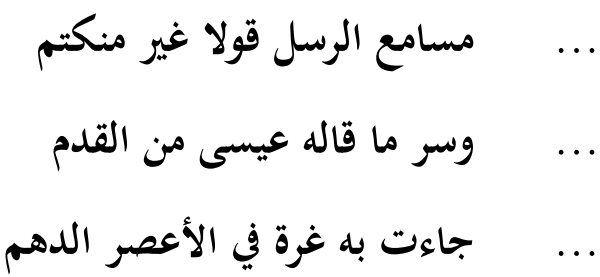

قد أبلغ الوحي عنه قبل بعثته

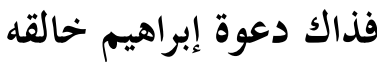

أكرم به وبآباء محجلة

في حسن البارودي عبارته نوع من البديع، ولكن شتان بين بديع وبديع ! أما البيت الأول فيعيد للأذهان قول البوصيري :

\section{محمد سيد الكونين والثقلين والفريقين من عرب ومن عجم}

وأما التقسيم الخماسي في البيت الثاني على سبيل الإضافة فيقوى الجرس ولكن يخرج به عن الإملال. وغزارة الصفات في البيتين الأولين بمثابة تقديم مؤهلات عظيمة لرسول عظيم. والبارودي بعد قد تحاشي تسييد محمد وتفضيله على الرسل الكرام، وإن كان فضله ضمناً بكل تلك الصفات الكريمة. إن هذا السياق التكريمي يدل على علو كعب النبي محمد في نظر أتباعه بحيث صار نموذجاً متحققا للفضائل كلها، عليهم أن يتبعوه .

بلغ من ذيوع احتفال المولد ( النبوي ) أن مولد كل ولي بل أي احتفال شعبي صار بمعنى ما مولداً. والمولد يستمر - كما اتضح - أياماً، وينتهي بالليلة الكبيرة التي استوحى منها الفنان صلاح جاهين عمله الملحمي المعروف بالليلة الكبيرة . وفي التراث التركي يعني " المولد " قصيدة في مديح الرسول صلى الله عليه وسلم، ولعل أقدمها هي مولد سليمان جبلي ( أو سليمان داده ) الذي نظمه سنة 1409 م، ويقع في ستمائة ثناثية. وقد حظى مولد جلبي - شأنه شأن البرد=ة بمعارضات كثيرة، وهو عادة ما يتلى في كل مناسبة دينية أو اجتماعية مثل الميلاد أو النجاح في امتحان ما (85) . وفي المقطع الذي اخترناه من " المولد " نلاحظ التبجيل الشديد للرسول باستخدام مفردات من بـ التراث العثامني، مثل التاج والعمامة الخاصين بالسلاطين، فضلاً عن المفردات القرآنية. يقول جبلي : ينتمي لخير نسل فلا أحد يضاهيه. إنه العزيز ذو الحسب النامي، الخير المقدس، ذو لمهابة، الذي توج بتاج الفضائل. والجميل الذي تزين بعمامة خير العمل .. إنه الأول والآخر : الأول في الفضل والهداية إلى الصراط القويم، والآخر الذي بعث بشيراً ونصيراً. إنه المبعوث إماماً هادياً لكل البشر، وهو الكريم 
الذي نرجو شفاعته يوم القيامة. هو المختار ذو أكرم عنصر، كاللؤلؤة المصنوعة المنفرةدة ... (86). ولعلنا نلاحظ تشاجها جذريا مع بعض ما تقدم من معاني المدائح مثل قول البوصيري بصدد الشفاعة :

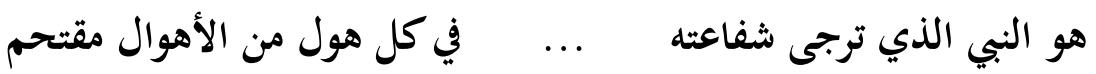
ولعلنا في حاجة إلى التذكير بما ظل بنو عثمان والأتراك كشعب يكنونه من تقدير للنبي محمد ( العربي الأمي ) وحرصهم على علم اللغة العربية، وقرض الشعر، وكان لبعضهم شعر صوفي في غاية

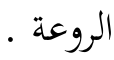

\section{نقد التصوف : 20 - نق}

من الظاهر أن التصوف زاد انتشاراً عقب سقوط بغداد وما تلاه من فتح القسطنطينية والخروج من الأندلس. انتشر لابو الرقاع والأسمال البالية، وعكفوا على البطالة والتسول في أحيان كثيرة، ولزموا التكايا والعمارات ( العثمانية المنشأ ). وكانت مصر حاضنة للأولياء القادمين من المشرق والمغرب. وقد انتقد كل من أحمد أمين وتوفيق الطويل (87) ذلك النمط التواكلي بدعوى التصوف، والحق أن ذلك كله صحيح ولكن بدرجة ما، فلا نكران أنه ظهرت الطرق الصوفية، ومنها المولية أو الصوفية الراقصة، وكانت - في بعض أوجهها - تأليفا عبقريا بين أرباب ديانات مختلفة كما في البلقان وبعض أصقاع أوروبا التي انتشر فيها الإسلام أحيانا عبر التصوف لأنه يبقى الوجه الإنساني الأكثر إشراقاً، وتقبلا للآخر ..ز كما بقيت الطرق والأنظمة الصوفية حافظة لتراث العلم والأدب والفنون بما أضفته على المريدين من رابطة قلبية تحاوز الأنانية والذات الفردية .

وأما في مصر، فلدينا نحن المصريين ميراث ثري من عقيدة أوزير وتجلى الأرباب في الطبيعة، وكان لكل ذلك أثره في المخيلة الشعبية التي وجدت ضالتها في مسلك الصوفية ( الفناء في الله، وحده الوجود، مقام الرضا والطمأنينة .. ). كما كانت الطرق الصوفية - كما يرى المؤرخ العظيم بيتر جران - حاضنة للعلم بمعناه الشامل، فلولاها لتبدد ما التأم من شمل العلماء في العصر الثماني خاصة. ويظل حديث التصوف متصلاً لا حسم فيه إلى ما شاء الله . لعلنا إذن في ضوء ما تقدم نعيد النظر إلى التصوف باعتباره إبداعاً شعبياً مصرياً، وتراثاً أصيلاً يتصل لا بتراث الإسلام وحده، بل يمتد إلى ما قبل الإسلام امتداد الحضارة المصرية ذاتها التي أبدعها

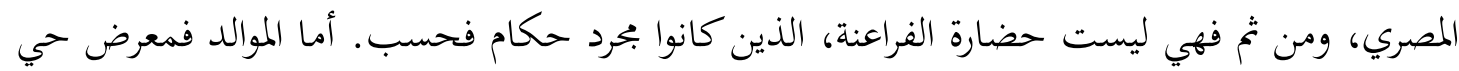


بابض بكل ما تحفظه الذاكرة الجمعية للأمة المصرية عبر عصورها. قد تكون المناسبة إسلامية أو مسيحية ن أو مصرية قديمة (كوفاء النيل ) ولكنها لها موالد في العرف الشعبي .

\section{| الهو|مشش|}

(1) لاحتفال المولد إذن مظاهر شتى، وخلفها يقوم الجوهر، وهو استلهام الجماهير لعظمة صاحب المولد، وبتحيد العهد على محاكاته والاقتداء به. ومن المفكرين من رأي أن للصفوة من الأنبياء والقادة والمبدعين دوراً كبيراً في حركة التاريخ. ومن أولئك أرنولد تويبي في : مختصر دراسة التاريخ، التي لخصها سمر فيلد وترجمها فؤاد شبل إلى العربية .

(2) راجع تفصيلاً : ر. أ. نيكلسون : الصوفية في الإسلام، ت. نور الدين شريبة، مكتبة الخانجي، القاهرة 1951، ص 4 وما بعدها. وقيل أيضاً أن الصوفية مشتقة من سوفيا أي الحكمة باليونانية وكان أتباع فيثاغورس يسلكون سبيل المحاهدة والتشقف، أو من الصفة كأبي ذر راجع. أحمد أمين : ظهر الإسلام، ط6، النهضة المصرية، القاهرة، جـ 4، ص 149 وما يليها .

I. Shah, Die Sufis : Bots chaft der Derwische, Weisheit der Magier. Eugen verl .. Koeln 1980. S. 7 ff.

$$
\begin{aligned}
& \text { (3) هي الأقرب إلى نظرية روح الشعب المرتبطة بالموقع الجغرافي فضلاً عن التراث الروحي للأمة . } \\
& \text { (4) راجع تفصيلا : نيكلسون : المرجع السابق، ص } 111 \text { وما يليها . }
\end{aligned}
$$

(5) وحلول اللاهوت في الناسوت على هذا النحو لا يعني وحدة الوجود إلا إذا انتفت الثنائية بينهما. لذا كان ابن عربي من المؤمنين بوحدة الوجود، وكذلك كان سبينوزا وجوته ( ت 1832 ) العظيم . (6) اتمم الحلاج بالشعوذة وادعاء الألوهية أو بأنه عصابي، وأنصفه ماسينيون إذ اعتبره صوفياً يجمع بين العقيدة الإسلامية والفلسفة اليونانية. ألف " الطواسين " ( يبدأ ب : طس ) ولغته عاطفية رمزية غريبة

وضع عنه ما سينيون دراسة وافية. تربمته في : Shah. op. cit .. 296 ff (7) طاف ابن عربي ببلاد منها الأندلس، سابقا سبينوزا ( ق 17 م ) الذي تأثر كثيراً بفكره راجع R. jockel, Islamische : عنه

(8) راجع تفصيلاً : أحمد أمين : المرجع السابق : 4 : 161، على سامي النشار : نشأة الفكر الفلسفي في الإسلام، ط1، دار المعارف، القاهرة، 1969، ص 43 وما يليها . 
(9) كان سقوط بغداد سنة 1258 م بأيدي المغول أحد أهم الأحداث الفارقة، إذ أكد سيادة العناصر غير العربية في دولة الإسلام . (10) راجع : محمد موفكاو : الثقافة الألبانية في الأبجدية العربية، عالم المعرفة، عدد 68، الكويت، أغسطس 1983، ص 128 . (11) محمد عبده الحجاجي : أبو الحجاج الأقصري - العالم الصوفي. دار التضامن، القاهرة، ب. ت. ن ص 140 ويليها .

(12) سعيد عبد الفتاح عاشور : السيد البدوي شيخ وطريقة، الهيئة العامة للكتاب، القاهرة، ص 258 وما يليها، وقد أفاض أوليا جلبي في وصف ذلك الاحتفال في سياحتنامة مصر حققه محمد عوني

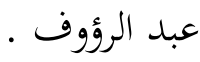

(13) تفضل مؤرخنا الكبير بإدارة الجلسة الأخيرة من سمينار تاريخ العصر الوسيط، وعلق كعادته تعليقاً ضافياً جاءت فيه هذه الملاحظة. كان ذلك يوم 15 يونيو سنة 2011، في الجمعية التاريخية المصرية والسمينار يدخل برعايته عامه التاسع ·

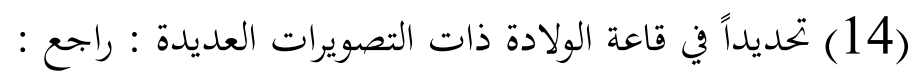

Posener \& Anderen, Lexikon Der Aegyptischen kultur. R. Loewit. Wiesbaden. S. S. 99 - 100

(15) فصلنا هذا الأمر في دراستنا : الديانة المصرية منذ لاهوت أون حتى رسالة التوحيد، القاهرة .2002

(16) كان يحتفل به في ذروة الصيف وقت الفيضان. راجع : سليم حسن : الحياة الدينية، وأثرها على البحتمع في : تاريخ الحضارة المصرية، لنخبة من العلماء، النهضة المصرية، القاهرة، ح1، ص 259 وما يليها. أ. إرمان : الديانة المصرية : هيئة الكتاب، ت. عبد المنعم أبو بكر، القاهرة، 2000، ص

223. فايز علي : الديانة المصرية : 203، أيضاً : 23 - Posener, op. cit, S. S. 22 (17) كان الناس يدخلون المسجد من بابه الواقع خلف صرح المعبد أي بداخله، ثم أصبح المدخل الجديد من خحارج المعبد .

Nogelsenzyk lopaedie : Aegyten, Nagel Verl., Genf 1981, S. S. 515 - 517. (18) B. Waterson, Introducing Egyptian Hieroglybhs. Scot. Acad. Press, Edinburgh 1981 , P. 115 s. a. Posener, Lexikon, S. 103. 
(19) تفصيل هذا البحث الأصلي وفيه تعريف باحتفالات كعيد الميلاد وعيد التتويج وعيد آمون

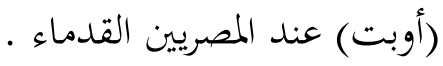

(20) Posener, op. cit., s 163

$$
\text { فايز علي : في فلسفة تاريخ مصر، القاهرة، 2001، ح 1، ص } 22 \text {. }
$$

(21) W. Budge, Osiris \& The Egyptian Resurrection. 2 vol., Dover Pub.. New York 1973 ( Medici 1911 ).

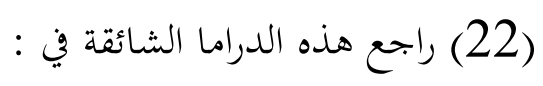

Fairman, The Triumph of Horus. London s. a. : Roeder ( herausg ), Urkunden Zur Religion Des Alten Aegypten, 1. Ausg.. E. Diderichs Verl.. Kolen 1978, S. 120 ff : s. a. Budge. Osiris, ff. p. 47.

(23) محمد سيد كيلاني : الأدب في مصر في ظل الحكم العثماني، دار الفرجاني، القاهرة، 1984،

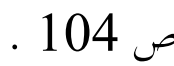

(24) هيرودوت يتحدث عن مصر، ت. محمد صقر خفاجة، هيئة الكتاب، القاهرة، ص 159 وما

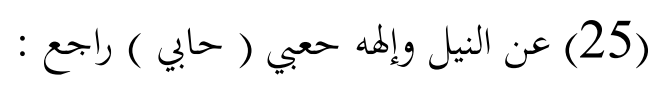

Budge, The Gods of The Egyptian, Dover pub.. I. ed New York 1969 ( London. Vol ff. p. 42 ff ( 1904 ).

$$
\text { (26) من لم يستطع لأبيدوس سبيلاً كان يرسل بلوحة تذكارية له لتدفن جوار معبد أوزير. راجع : Feve }
$$

A. Zayed, Abydos, antiq services organiz.. Cairo; F. Petrie, Abydos: Egypt Exp. Fund, London 1902 .

(27) Budge. Osiris. Ll. P. 1 ff: s. a. Posener. Lexikon, S. 189 ff :

$$
\begin{aligned}
& \text { وكذا كتاب زيتيه ( بالألمانية ) عن طقوس أوزير السحرية . } \\
& \text { (28) هيرودوت : المرجع السابق، ص } 165 \text {. } \\
& \text { (29) كيلاني : المرجع السابق : } 104 \text {. }
\end{aligned}
$$

(30) هو أبو الحسن محمد بن الحسين الرضى العلوي الموسوي. راجع ترجمته في طه حسين وآخرين :

$$
\begin{aligned}
& \text { المنتخب من أدب العرب، مط، دار الكتب، القاهرة 1932، ح1، ص } 33 \text {. } \\
& \text { (31) الحجاجي : المرجع السابق : ص } 87 \text {. }
\end{aligned}
$$


(32) الحجاجي : المرجع السابق : ص 88 وما يليها .

(33) الحجاجي : المرجع السابق : 144 .

(34) وضحنا ذلك تفصيلاً في دراسة لنا عنواها : معبد الأقصر، القاهرة 1989 . (35) انظر ابن القيم الجوزية : زاد المعاد في هدي خير العباد، 1353، 1934، ح1، ص 52 . (36) هو أبو حفص عمر البغدادي ( 1145 - 1234 م ) صوفي وفقيه شافعي ألف " جذب القلوب "و " عوارف المعارف " .. وهو غير السهروردي المقتول ( 1191 ) . (37) أندريه يمون : الحرفيون والتجار في القاهرة في القرن الثامن عشر، ت. إبراهيم - جمال الدين، ط1، عدد 818، م. أ. للثقافة، القاهرة 2005، ح2، ص 765 وما يليها . (38) وهي التي تتبأت لأوديب ابن لايوسملك طيبة ( اليونان ) بنهايته المأساوية إذ يقتل أباه ويتزوج أمه ( جوكاستا ). راجع : المعجم الكلاسيكي : ص 256 - 259 - في : لويس عوض : نصوص النقد الأدبي، ح1، هيئة الكتاب، القاهرة، 1989 ـ (39) حض الرسول على العمل، إذ روي عنه : " خير الكسب كسب يد العامل إذا نصع " ( السيوطي : الجامع الصغير في أحاديث البشير النذير، دار الطباعة العامرة بمصر 1286 خـ ن 1 :

(40) العزالي ( أبو حامد محمد : ت 1111 م ) : مكاشفة القلوب المقرب من علام الغيوب، تح. عبد الله أحمد أبو زينة، دار الشعب، القاهرة، ب. ت ص 29 ـ 29 (41) أدت العذراء - في المعتقد الشعبي - دور إيزيس ( أم الإله حور ). وقد نزهها الله في سورة

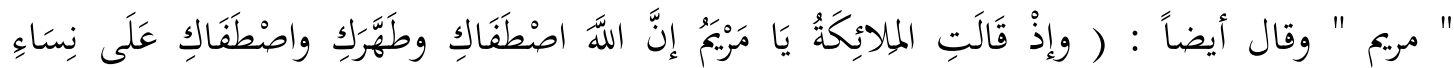

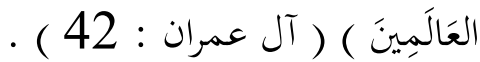

(42) راجع تفصيلاً : مرسيا إلياد : التسيب والولادات الصوفية، ت. حسيب كاسوحة، وزارة الثقافة،

$$
\text { دمشق 1999، ص } 29 \text { وما يليها . } 143 \text { (43) الحجاجي : المرجع السابق : } 175 \text {. }
$$

J. W. Goethe, : West - oestlicher Divan. S. 305 ff - in : Goethe Werke WBG, Darmstadt 1998. 
(45) سعيد عاشور : السيد البدوي : ص 258 ومواضع أخرى، وجامعه أنشأه علي بك الكبير على

$$
\text { مقامه الشهير. قارن : الجبرتي : م. س : } 1 \text { : } 501 \text {. } 5 \text { معيد عاشور : المرجع السابق : نفس الموضع . }
$$

(47) سعيد عاشور : المرجع السابق، ويضيف أوليا جلبي أن قصيدة المولد كانت تتلى في مثل تلك الاحتفالات : جلبي : سياحتنامة مصر : 581 وما يليها عن " احتفال مشايخ الطريقة البدوية بمولد شيخهم ... وذلك على عهد السلطان محمد الرابع : 1648 - 1687 . (48) سعيد عاشور : المرجع السابق : 155 وما يليها . (49) شيدفار : حول نشوء وأسلوب السيرة الشعبية العربية - في : بحوث سوفيتية جديدة في الأدب العربي، دار رادوغا موسكو، ص 83 - 84. وسيف تحالف مع كسري لتحرير بلاده من الجيش : أحمد الحويف : تيارات ثقافية بين العرب والفرس، غضة مصر، القاهرة 1968، ص 16 وما يليها . (50) راجع ابن كثير ( أبو الفداء عماد الدين اسماعيل : ت 774 / 1372 ) : صفوة السيرة،

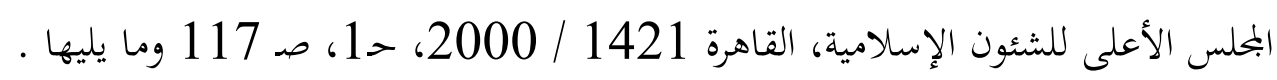
(51) علي مبارك : الخطط التوفيقية الجديدة لمصر القاهرة، هيئة الكتاب، القاهرة، 1983، ح1، ص ص 231، قارن بوصف الجبرتي للمولدين الحسيني والنبوي في عجائب الآثار في التراجم والأخبار، مط الأنوار المحمدية، ح 4، ص 249، 309، وما يليها. وعن احتفالات البكرية بالمولد النبوي :علي مبارك، المرجع السابق : 3 : 440 . (52) جومار : وصف مدينة القاهرة وقلعة الجبل، ت. أيمن فؤاد سيد، ط1، مكتبة الخانجي، القاهرة 1988/1408، ص 315 - 316. وبريستد حدثنا في فجر الضمير عن طقوس الإنارة لدى احتفال وبواووت وأنوبيس في معبدهما بأسيوط، إذ كانت تبدو الأنوار في الظلام الدامس كجزيرتين منعزلتين . (53) في محاضرتا عن المولد بالمعهد الألماني للأثار بالقاهرة في ديسمبر 2010 . (54) راجع : محمد عزيزة : الإسلام والمسرح ن هيئة الكتاب، القاهرة، 1990، ص 86 وما يليها. وقد اطلع المؤلف على النص الفارسي ( في 33 بحلساً ) بعنوان : جوبجي شيهادات ( نشيد الشهيد ). ووصف علي مبارك عادات الأعاجب المقيمين في القاهرة لدى موالد النبي وآل البيت وأول المحرم وليلة 
عاشوراء : خطبهم ورثانياقم والنوح والتعديد .. الخ. راجع : علي مبارك : الخطط التوفيقية : 1 : 21 وما يليها .

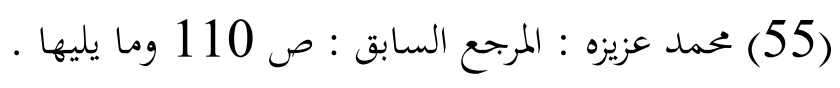

(56) محمد موفاكو : المرجع السابق 132 / 133 والدلدل نظير البراق. حدث عنه الغزالي في : مكاشفة القلوب : 230 وما يليها قارن :

Kreiser \& Anderen. Lexikon der islamischen Welt, Kohlhammer, Stutgart 1974, B2. S. 231 .

$$
\text { (57) موفاكو : المرجع السابق : } 153 \text {. }
$$

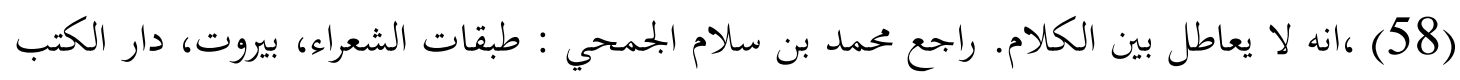

$$
\text { العلمية، } 1400 \text { / 1980، ص } 29 \text {. }
$$

وعن حياة كعب ونتاجه العلمي : ص 37 وما يليها. أيضاً : ديوان كعب بن زهير، صنعة أبو سعيد الحسن العسكري، تقديم حنا نصر الحتي : دار الكتاب العربي، بيروت 1429 / 2008 ؛ ص 7 وما (59) عده العلامة حسين المرصفي ( ت 1889 م ) من الشعراء الأمراء في : الوسيلة الأدبية وقد ورد في سيرته الشعبية إرهاصات ببعثة محمد . (60) حسان بن ثابت عرف بشاعر الرسول : إذ انبرى للدفاع عنه وعن دعوته .

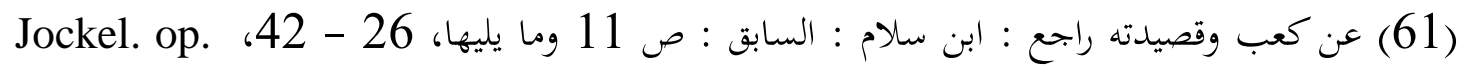
cit.. S. 67 ff

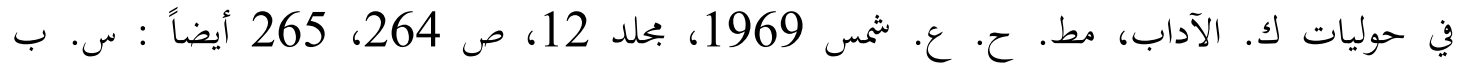
ستيتكيفيتس : القصيدة والسلطة، ت. حسن البنا، م. ق. للترجمة، عدد 1527. ط1، القاهرة 2010، ص ص ع . 79 (62) راجع ترجمته في : Jokel. op. cit.. S. 241 : كيلاني : الحروب الصليبية وأثرها في الأدب في مصر

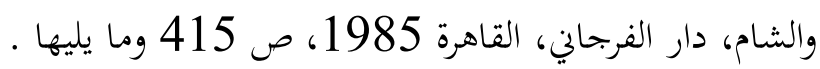
(63) راجع : كيلاني : المرجع السابق : 54 وما يليها. وقارن : ديوان البوصيري، ت. محمد سيد كيلاني، القاهرة 1973، مواضع متفرقة . 
(64) ابن شاكر الكتبي : فوات الوفيات، تح. إحسان عباس، دار صادر، بيروت، ح3، ص 368 ما يليها .

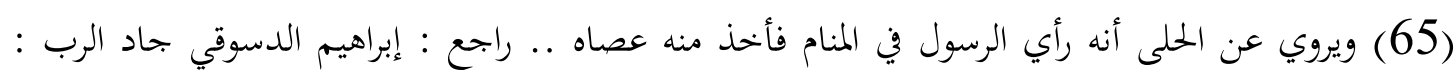
حول البردة، مركز ج. القاهرة للنشر، 1997 ن ص 21 وما يليها سيرد عن البارودي نفس الخبر أيضا .

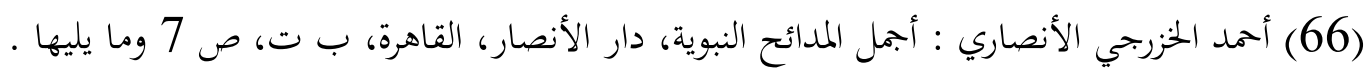
(67) هو أبو محمد عبد الملك الحميري البصري ( المولد ) مصري الدار، شرح سيرة ابن اسحق وكتب سيرته

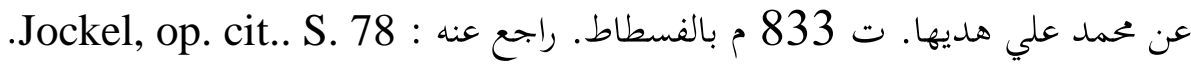
(68) هذا دليل الإجادة ( الفنية ) الذي يدحض انتقاد النقاد. راجع : فايز علي : الرمزية والرومانسية في

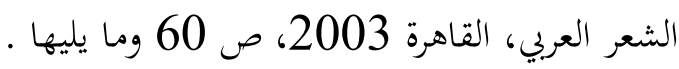

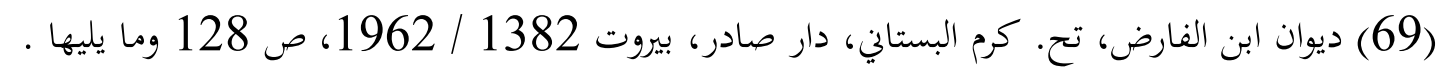

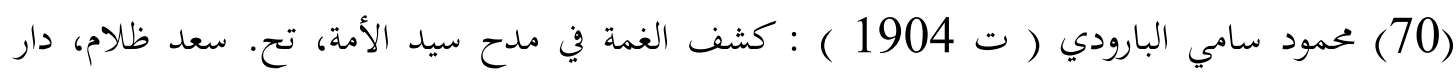

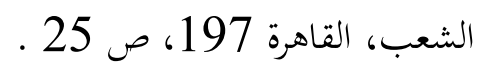

(71) كما في قول فوجلفايدة ( ت ح 1230 م ) - شاغر بلاط فريدريك الثاني : " عرفت كيف تجرحني.

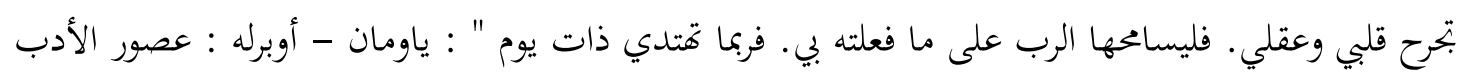

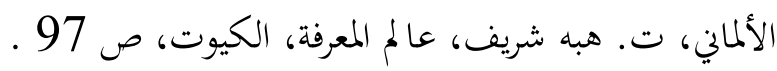
(72) أضافت المخيلة الشعبية كثيراً من الروايات مثل رواية الحمام والعنكبوت .. ومبالغات عن قدم النور المحمدي ..

(73) راجع : سهير القلماوي - محمود مكي : في الأدب - عن شعر الملاحم والمسرح - في : أثر العرب

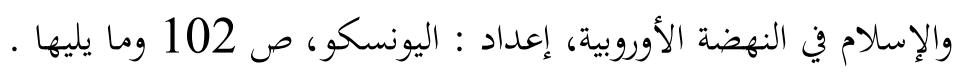
(74) تكفي مثل هذه المقاطع الوجدانية لتدحض الزعم بأن كشف الغمة بحرد سيرة حياة .

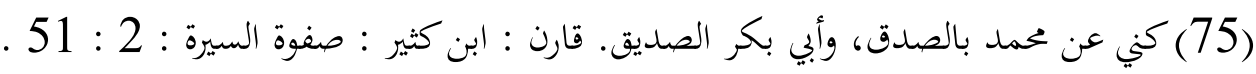
(76) زكي مبارك : المدائح النبوية في الأدب العربي، دار الشعب. القاهرة، ب. ت : مواضع متفرقة. وعن غزوة بدر : ابن كثير : صفوة السيرة : 2 : 179. وعن سائر غزواته ( أيامه ) صلى الله عليه وسلم : مغازي الواقدي. تح. مارسدن جونز، مط ج. أكسفورد، دار المعارف، القاهرة 1966 . (77) أحمد شوقي : الشوقيات - في السياسة والتاريخ والاجتماع، دار العودة، بيروت ن حـ1، ص صدرة 203. ومن قصيدته فه البردة .

(78) قارن ذلك بقول شوقي ( في : الشوقيات : 1 : 195 ) : 


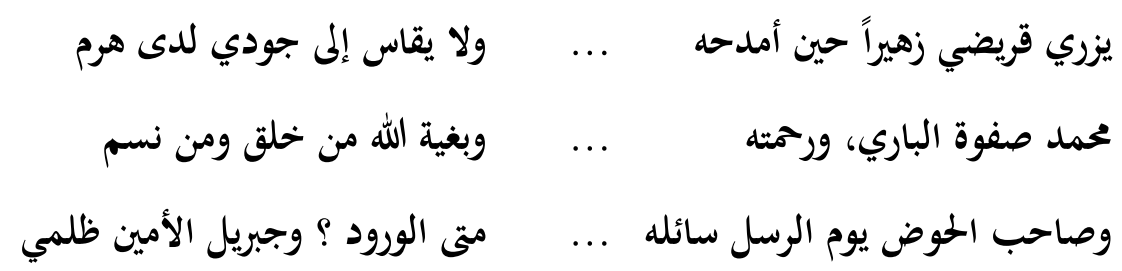

(79) لعل البارودي تأثر بنظامي كنجوي إذ يتضرع إلى الله في مناجاة خاشعة ذات مفردات مشاهمة كالخدمة

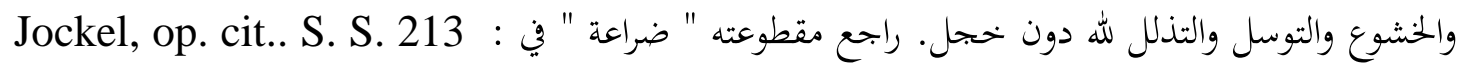

(80) راجع تفصيلا : أحمد أبو زيد : البديعيات في الأدب العربي - نشأقا - تطورها - أثرها، ط1، عالم الكتب، بيروت 1983، ص 41، 55 وما يليهما .

(81) المرادي : سلك الدور في أعيان القرن الثاني عشر، ط. بولاق 1301 هـ، 3 : 30 - 38، الجبرتي : عجائب الأثار : 1 : 201 : 201 : (82) أبو زيد : البديعيات : ص 75 وما يليها : : (83) أبو زيد : البديعيات : 78 وما يليها .

(84) أبو زيد : البديعيات : 76 وما بعدها ومواضع متفرقة. أيضا : إبراهيم الدسوقي جاد الرب : حول

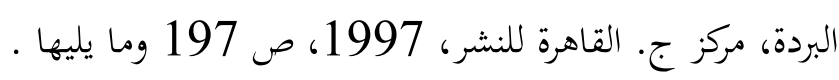

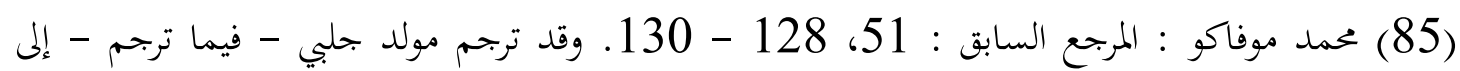
الألبانية أيضا .

(86) Jockel, op. cit.. S. 262.

(87) راجع كلاً من : أحمد أمين : ظهر الإسلام : c 63 وما يليها، توفيق الطويل : التصوف إبان العصر

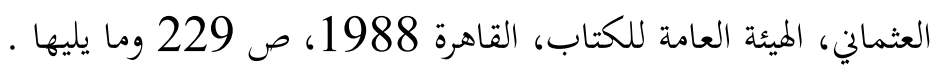

